\title{
Light absorption and morphological properties of soot-containing aerosols observed at an East Asian outflow site, Noto Peninsula, Japan
}

\author{
Sayako Ueda ${ }^{1, *}$, Tomoki Nakayama ${ }^{1, * *}$, Fumikazu Taketani $^{2}$, Kouji Adachi $^{3}$, Atsushi Matsuki $^{4}$, Yoko Iwamoto $^{4, * * *}$, \\ Yasuhiro Sadanaga ${ }^{5}$, and Yutaka Matsumi ${ }^{1, * *}$ \\ ${ }^{1}$ Solar-Terrestrial Environment Laboratory, Nagoya University, Nagoya, Japan \\ ${ }^{2}$ Japan Agency for Marine-Earth Science and Technology, Yokohama, Japan \\ ${ }^{3}$ Atmospheric Environment and Applied Meteorology Research Department, Meteorological Research Institute, \\ Tsukuba, Japan \\ ${ }^{4}$ Institute of Nature and Environmental Technology, Kanazawa University, Kanazawa, Japan \\ ${ }^{5}$ Graduate School of Engineering, Osaka Prefecture University, Sakai, Japan \\ * now at: Graduate School of Environmental Studies, Nagoya University, Nagoya, Japan \\ ** now at: Institute for Space-Earth Environmental Research, Nagoya University, Nagoya, Japan \\ *** now at: Faculty of Science Division I, Tokyo University of Science, Tokyo, Japan
}

Correspondence to: Sayako Ueda (ueda-s@stelab.nagoya-u.ac.jp) and Tomoki Nakayama (nakayama@stelab.nagoya-u.ac.jp)

Received: 12 August 2015 - Published in Atmos. Chem. Phys. Discuss.: 15 September 2015

Revised: 19 January 2016 - Accepted: 10 February 2016 - Published: 2 March 2016

\begin{abstract}
The coating of black carbon (BC) with inorganic salts and organic compounds can enhance the magnitude of light absorption by BC. To elucidate the enhancement of light absorption of aged $\mathrm{BC}$ particles and its relation to the mixing state and morphology of individual particles, we conducted observations of particles at an Asian outflow site in Noto Peninsula, Japan, in the spring of 2013. Absorption and scattering coefficients at 405, 532, and $781 \mathrm{~nm}$ and mass concentrations/mixing states of refractory $\mathrm{BC}$ in $\mathrm{PM}_{2.5}$ were measured using a three-wavelength photoacoustic soot spectrometer and a single-particle soot photometer (SP2), respectively, after passage through a thermodenuder (TD) maintained at 300 or $400^{\circ} \mathrm{C}$ or a bypass line maintained at room temperature $\left(25^{\circ} \mathrm{C}\right)$. The average enhancement factor of BC light absorption due to coating was estimated by comparing absorption coefficients at $781 \mathrm{~nm}$ for particles that with and without passing through the TD at $300^{\circ} \mathrm{C}$ and was found to be 1.22. The largest enhancements $(>1.30)$ were observed under high absorption coefficient periods when the air mass was long-range transported from urban areas in China. Aerosol samples were also analyzed using a transmission electron microscope (TEM) equipped with an energy dispersive $\mathrm{X}$ -
\end{abstract}

ray analyzer. The morphological features and mixing states of soot-containing particles of four samples collected during the high absorption events were analyzed by comparing microphotographs before and after the evaporation of beamsensitive materials by irradiation with a high-density electron beam. The majority of the soot in all samples was found as mixed particles with sulfate-containing spherules or as clusters of such spherules. For samples showing high enhancement (> 1.30) of BC light absorption, the TEM showed that the internally mixed soot-containing particles tended to have a more spherical shape and to be thickly coated. The SP2 measurements also suggested that the proportion of thickly coated soot was greater. Thus, the observed enhancement of BC light absorption was found to differ according to the mixing states and morphology of soot-containing particles. The enhancement of BC light absorption in our in situ measurements and its relation with individual features of sootcontaining particles will be useful to evaluate direct radiative forcing in the downwind areas of large emission sources of $\mathrm{BC}$. 


\section{Introduction}

Black carbon (BC) is contained in particles emitted from fossil fuel combustion and biomass/biofuel burning. It is known as a strong absorber of visible spectrum solar radiation in the atmosphere (e.g., Ramanathan and Carmichael, 2008; Bond et al., 2013). Similar to greenhouse gases, this absorption by $\mathrm{BC}$ is thought to lead to large positive radiative forcing; however, this assumption remains uncertain (IPCC, 2013). In the estimation of direct radiative forcing by $\mathrm{BC}$ particles, understanding how to treat the mixing state and optical properties of the $\mathrm{BC}$ and other materials is particularly important for reducing this uncertainty (Ma et al., 2012). In relation to the global effect of BC, marked anthropogenic emissions of pollutants by recent economic development in eastern Asia is an important consideration (Streets et al., 2003; Ohara et al., 2007; Kurokawa et al., 2013). In addition to BC, precursor gases of secondary aerosol materials have been heavily emitted in eastern Asia (Bond et al., 2004; Kurokawa et al., 2013).

$\mathrm{BC}$ is operationally defined as a carbonaceous material with a deep black appearance caused by a significant imaginary portion of the refractive index. It roughly corresponds with elemental carbon (EC), which refers to the nonvolatile carbon present below a certain temperature (typically $550^{\circ} \mathrm{C}$ ) (Andreae and Gelencsér, 2006; Bond and Bergstrom, 2006). Carbonaceous particles originating from fossil fuel combustion are observed as soot by electron microscope (e.g., Murr and Soto, 2005). Soot has an aggregation morphology of globules with a diameter of tens of nanometers that consist of concentrically wrapped graphitic layers (Pósfai et al., 2004; Murr and Soto, 2005). Although the definitions of soot and BC are different, they were considered equivalent for the purposes of this work. Soot particles that are freshly emitted by fossil fuel combustion are attached/coated with secondary aerosol materials, such as sulfate, nitrate, and organics, through atmospheric aging processes (Weingartner et al., 1997; Zuberi et al., 2005). Atmospheric aging processes of aerosol particles include adsorption and condensation of semi-volatile materials, coagulation of particles with other pre-existing aerosol particles, heterogeneous reactions at the particle surface with gaseous species, and cloud processing in the atmosphere (Fuchs, 1964; Husar and Whitby, 1973; Mamane and Gottlieb, 1989; Meng and Seinfeld, 1994; Ueda et al., 2014).

Several studies using electron microscopy have reported that soot particles tend to be coated with large amounts of secondary materials in an aged air mass, whereas air masses in urban areas contain some uncoated soot particles (Pósfai et al., 1999; Hasegawa et al., 2002; Vester et al., 2007; Ueda et al., 2011; Adachi et al., 2014). Ueda et al. (2011) reported that in leeward areas, soot-containing particles were internally mixed with the largely soluble materials in polluted air masses transported from eastern Asia. Moreover, a fraction of the soot-containing particles had an irregular shape due to mixing with clusters of spherical sulfate, which are consid- ered to be generated by coagulation processes under dry and high aerosol concentration conditions.

The presence of coatings on $\mathrm{BC}$ particles is known to enhance the magnitude of light absorption by the $\mathrm{BC}$ particles, referred to as the "lensing effect". The enhancement of light absorption by $\mathrm{BC}$ particles by coating $\left(E_{\mathrm{abs}}\right)$ is expressed as the ratio of light absorption of coated $\mathrm{BC}$ particles to uncoated BC particles. Models often apply a constant $E_{\text {abs }}$ value or estimate $E_{\text {abs }}$ assuming a core-shell(the $\mathrm{BC}$ core and coating materials) shaped spherical particle (Bond et al., 2013, and references therein). However, several studies have indicated that estimation assuming a coreshell structure with a clear shell tends to overestimate the $E_{\text {abs }}$ values (Lack and Cappa, 2010; Adachi et al., 2010). Lack and Cappa (2010) estimated $E_{\text {abs }}$ of BC particles coated by brown carbon based on calculations using core-shell Mie theory. They showed that the lensing effect can be reduced from the non-absorbing coating case by up to 25-30\% when averaged across the visible radiation spectrum. For Mexico City, Adachi et al. (2010) obtained three-dimensional shapes of soot-containing particles embedded in organic matter and sulfate using electron tomography with a transmission electron microscope (TEM), and calculated the optical properties using a discrete dipole approximation. They reported that the core-shell model overestimated light absorption by $\sim 30 \%$ compared to the model for irregularly shaped soot-containing particles.

Recently, the $E_{\text {abs }}$ values have been measured by several studies based on in situ measurement of optical properties, using photoacoustic spectrometers (PAS) with a thermodenuder (TD). The reported $E_{\text {abs }}$ values are from nondetectable to 1.43 in Toronto (Canada) (Knox et al., 2009; Chan et al., 2011; Healy et al., 2015), 1.38 in Boulder (USA) (Lack et al., 2012), 1.06 in California (USA) (Cappa et al., 2012), 1.10 (August) and non-detectable (January) in Nagoya (Japan) (Nakayama et al., 2014), and 1.4 at Detling (UK) (Liu et al., 2015). In these studies, $E_{\text {abs }}$ was estimated as the ratio between absorption of ambient particles and particles heated in a TD to remove non-BC materials. However, there have been very few observational studies reported the contributions of lensing effect and their relation with morphology of individual BC-containing particles in a well-aged air mass.

To elucidate the enhancement of light absorption of aged BC particles of Asian outflow and their relation with the amount, morphology, and composition of coating materials, we conducted atmospheric observations of continental outflow at Noto Peninsula, Japan, in spring 2013. This atmospheric observation site has been previously used to study continental outflow (Maki et al., 2010; Iseki et al., 2010; Ishiyama et al., 2015). In the present study, the absorption and scattering coefficients of aerosol particles were directly measured using a $3 \lambda$-photoacoustic spectrometer (Droplet Measurement Technologies, PASS-3) with and without passage through a TD, and the contribution of the lensing effect 
was estimated. Specific attention was given to the relations between the enhancement of light absorption and the coating condition of individual soot-containing particles based on the TEM analysis.

\section{Field observation and laboratory analysis methods}

\subsection{Observation site and instrumentation}

Atmospheric observations were conducted at NOTO Ground-based Research Observatory (NOTOGRO) in Suzu, Japan $\left(37.5^{\circ} \mathrm{N}, 137.4^{\circ} \mathrm{E}\right)$, from 17 April to 14 May 2013. Suzu City is located on the north coast of Noto Peninsula. The physical and chemical parameters of aerosol particles and the concentrations of gaseous species have been continually monitored at the site. Ambient air was sampled through a $\mathrm{PM}_{10}$ inlet that was placed $14.7 \mathrm{~m}$ above the ground. Each measurement system was set in a room and connected to a flow splitter downstream of the $\mathrm{PM}_{10}$ inlet.

Chemical constituents of the aerosols were assessed using an aerosol chemical speciation monitor (ACSM, Aerodyne Research) capable of monitoring the bulk chemical components (organics, $\mathrm{NH}_{4}^{+}, \mathrm{SO}_{4}^{2-}, \mathrm{NO}_{3}^{-}$, and $\mathrm{Cl}^{-}$) of non-refractory submicrometer-sized aerosols $\left(\mathrm{NR}-\mathrm{PM}_{1}\right)$. A $\mathrm{PM}_{2.5}$ cyclone (with a cut-off size of $2.5 \mu \mathrm{m}$ at a flow rate of $3 \mathrm{~L} \mathrm{~min}^{-1}$ ) was installed upstream of the ACSM inlet to remove coarse particles. The ionization efficiency of nitrate and the relative ionization efficiency of ammonium were determined by the standard calibration procedure ( $\mathrm{Ng}$ et al., 2011) using $\mathrm{NH}_{4} \mathrm{NO}_{3}$ (99.5\%, Strem Chemicals). A collection efficiency (CE) of 0.3 was applied to the ACSM data. The value of CE was determined by comparing the mass concentrations of ammonium and sulfate derived by the ACSM to those measured by a conventional filter-based offline chemical analysis. The procedures to determine the CE value are described in the Supplement (S1). Data for the chemical constituents were obtained every $30 \mathrm{~min}$. During our observation period, more than $90 \%$ of the measured nonrefractory materials were $\mathrm{SO}_{4}^{2-}, \mathrm{NH}_{4}^{+}$, and organics by mass. A particle size distribution between 8 and $346 \mathrm{~nm}$ in diameter was measured by a scanning mobility particle sizer (SMPS) (TSI, model 3936L76) placed downstream of the $\mathrm{PM}_{10}$ inlet. We set additional systems in the flow splitter downstream of the $\mathrm{PM}_{10}$ inlet during this observation campaign, as shown in Sects. 2.2 and 2.3.

The concentrations of $\mathrm{NO}_{x}$ and $\mathrm{NO}_{y}$ were measured using a NO- $\mathrm{O}_{3}$ chemiluminescence detector (Thermo Fisher Scientific, model 42i-TL) with a near-UV LED photolytic converter and a molybdenum reduction catalyst (Mo converter) (Thermo Fisher Scientific, part no. 9445) heated to 598 K, respectively. Detailed information for these measurements of $\mathrm{NO}_{x}$ (Sadanaga et al., 2010) and $\mathrm{NO}_{y}$ (Sadanaga et al., 2008; Yuba et al., 2010, 2014) has been given previously.

\subsection{In situ measurements of optical and physical properties of particles with and without passage through the TD}

A schematic diagram of the experimental setup to measure the optical and physical properties of particles with or without passage through a TD is presented in Fig. 1. Coarse aerosol particles were removed by a $\mathrm{PM}_{2.5}$ cyclone (URG, URG-2000-30EH). After being dried by diffusion dryers with silica gel, the sample air was introduced alternately to a reference line and two TD lines to measure, respectively, ambient particles directly and refractory particles after the evaporation of volatile materials under high-temperature conditions. The same type of TDs used in our previous studies (Guo et al., 2014; Nakayama et al., 2014) was used in this study. The TD consists of a stainless tube (outer and inner diameters: 12.7 and $10.2 \mathrm{~mm}$, respectively; length: $600 \mathrm{~mm}$ ) and electronic jacket heaters (Heater Engineer, P-series). Flow rates through the TD was $1.28 \mathrm{~L} \mathrm{~min}^{-1}$, and the residence time for the sample aerosols in the TD was estimated to be $2.3 \mathrm{~s}$, on the assumption of plug flow conditions (at $20^{\circ} \mathrm{C}$ ). The temperatures of the two TDs were maintained at 300 and $400^{\circ} \mathrm{C}$. The lines were switched every $10 \mathrm{~min}$ using two-way ball valves. Then, the sample air was introduced to the PASS-3, another SMPS (TSI, model 3936L72), and a single-particle soot photometer (Droplet Measurement Technologies, SP2). The sampling flow rates of the PASS3, SMPS, and SP2 were 1.0, 0.2, and $0.08 \mathrm{~L} \mathrm{~min}^{-1}$, respectively. The relative humidity in the cell of the PASS-3 was lower than $11 \%$ throughout the observation period.

The SMPS was used to measure the particle size distribution between 18 and $982 \mathrm{~nm}$ in diameter every $5 \mathrm{~min}$. The SP2 was used to measure the mass concentration, size, and mixing state of single refractory $\mathrm{BC}(\mathrm{rBC})$ particles. The SP2 is based on the laser-induced incandescence (LII) method. The basic measurement principle of SP2 has been described previously (Gao et al., 2007; Moteki and Kondo, 2007). Before and after measurement, calibration of $\mathrm{rBC}$ was performed by measuring the LII signal intensities from sizespecified fullerene particles (Alfa Aesar; stock 40971, lot L20W054) generated by an atomizer through a differential mobility analyzer (DMA) (TSI, model 3080). The size of $\mathrm{rBC}$ was derived by assuming sphericity and a fixed density of $1.8 \mathrm{~g} \mathrm{~cm}^{-3}$. The mixing state of $\mathrm{rBC}$-containing particles was qualitatively estimated by the lag time of the LII peak with respect to the peak of the scattering signal (Moteki and Kondo, 2007). Use of the SMPS in our measurement system was ended on 13 May, while use of the PASS-3 and SP2 was ended on 14 May.

The PASS-3 instrument was used to measure the absorption $\left[b_{\text {abs }}(\lambda)\right]$ and scattering $\left[b_{\text {sca }}(\lambda)\right]$ coefficients at 405 , 532 , and $781 \mathrm{~nm}$. Details of the performance and calibration procedures of the PASS-3 have been described elsewhere (Nakayama et al., 2013, 2015). Note that the absolute values of the calibration factors do not influence to the $E_{\text {abs }}$ 


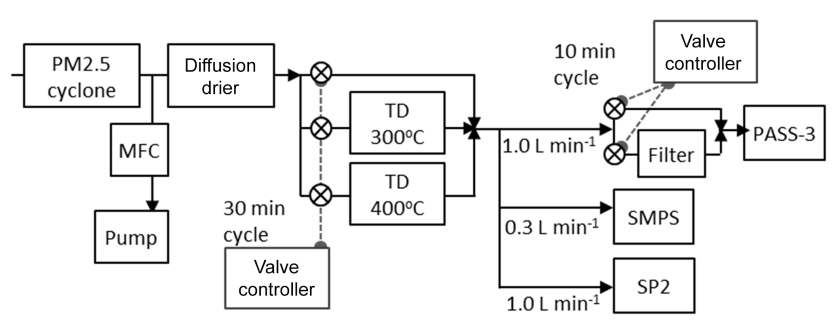

Figure 1. Flow diagram of a measurement system for dried particles that did and did not pass through the thermodenuders (TDs) maintained at 300 and $400^{\circ} \mathrm{C}$ using the PASS-3, SMPS, and SP2. Black arrow lines indicate the flow lines of sample air.

values, which are used for discussion in the present study. The $b_{\text {sca }}(532 \mathrm{~nm})$ data were not used in this study because of a strong particle size dependence of the calibration factor at $532 \mathrm{~nm}$ (Nakayama et al., 2015). For background interpolation, measurements of filtered air were conducted using a particulate filter (Balston) for $3 \mathrm{~min}$ every $10 \mathrm{~min}$. The influence of light absorption of $\mathrm{NO}_{2}$ was found to be small $\left(<0.05\right.$ and $<0.04 \mathrm{Mm}^{-1}$ at 405 and $532 \mathrm{~nm}$, respectively) based on the estimation using transmittance of $\mathrm{NO}_{2}$ through filter and inlet tube as well as mixing ratio of $\mathrm{NO}_{2}$, and was taken into account for the determination of $b_{\mathrm{abs}}$ values. The $3 \mathrm{~h}$ averaged values for each sampling line were estimated from six sets of $10 \mathrm{~min}$ data. By taking 2 standard deviations $(2 \sigma)$ of each signal during the filtered air measurements, the typical detection limits for the $3 \mathrm{~h}$ averaged data of $b_{\text {abs }}(405 \mathrm{~nm}), b_{\text {abs }}(532 \mathrm{~nm}), b_{\text {abs }}(781 \mathrm{~nm}), b_{\text {sca }}(405 \mathrm{~nm})$, and $b_{\text {sca }}(781 \mathrm{~nm})$ were estimated to be $1.0,1.9,1.1,0.7$, and $0.3 \mathrm{Mm}^{-1}$, respectively. Note that these detection limits varied depending on the magnitude of the drift in each signal.

In our system, particle loss and charring can occur in the TD lines. Using thermal/optical methods, some analytical studies of elemental and organic carbon in atmospheric particles reported that the degree of increase in light absorption of particles by charring differed among different organic material compositions (Yang and Yu, 2002; Yu et al., 2002). Based on the measurement of absorption at $680 \mathrm{~nm}$ wavelength under He-induced conditions, Yang and Yu (2002) showed that charring of a sample including a large amount of water soluble organic carbon can increase from around $400^{\circ} \mathrm{C}$. The charring effect can vary depending on the aerosol composition and, therefore, with time. In this observation, the ratios of the mass concentration of $\mathrm{rBC}$ measured by the SP2 without heating $\left[m_{\mathrm{rBC}}\left(25^{\circ} \mathrm{C}\right)\right]$ to that after heating $\left[m_{\mathrm{rBC}}(T)\right]$ $\left(T=300\right.$ and $400^{\circ} \mathrm{C}$ ) varied depending on time with averages $( \pm 1 \sigma)$ of $1.08 \pm 0.28$ and $1.03 \pm 0.30$ at 300 and $400^{\circ} \mathrm{C}$, respectively. Considering the estimated particle loss in our $\mathrm{TD}\left(\sim 17\right.$ and $\sim 20 \%$ at 300 and $400^{\circ} \mathrm{C}$, respectively; Guo et al., 2014), our results suggest that non-negligible amount of $\mathrm{rBC}(10-20 \%$ of ambient $\mathrm{rBC})$ were formed in the TD, possibly due to charring by heating. In the present study, the $E_{\mathrm{abs}}$ values were estimated by taken these effects into account, as- suming that light-absorbing property of ambient $\mathrm{rBC}$ is same with that of $\mathrm{rBC}$ formed by heating in the TD and detected by the SP2,

$E_{\mathrm{abs}}(\lambda, T)=\frac{b_{\mathrm{abs}}\left(\lambda, 25^{\circ} \mathrm{C}\right) / b_{\mathrm{abs}}(\lambda, T)}{m_{\mathrm{rBC}}\left(25^{\circ} \mathrm{C}\right) / m_{\mathrm{rBC}}(T)}$,

where $\lambda$ and $T$ were measurement wavelength and TD temperature, respectively.

\subsection{Samples of individual particles and TEM analyses}

Aerosol particles were collected for morphological analysis using TEM (JEM-1400; JEOL). The sampling line for TEM analysis was placed downstream of the $\mathrm{PM}_{10}$ inlet. To analyze particles under the same conditions as PASS3 and SP2, dried aerosols (after passage through diffusion dryers) were collected using a two-stage cascade impactor (50\% cutoff aerodynamic diameters of the two stages were 1.5 and $0.3 \mu \mathrm{m}$ at a flow rate of $0.7 \mathrm{~L} \mathrm{~min}^{-1}$ ) on carboncoated nitrocellulose (collodion) films. In this study, samples from the second stage ( $50 \%$ cut-off diameter of $0.3 \mu \mathrm{m}$ ) were analyzed. Aerosol samples were collected for 10-20 min. Typically, 1-2 samples were taken per day during the campaign. A fraction of the samples was collected after passing the particles through the same type of TDs used for the in situ measurements (Sect. 2.2) maintained at 300 or $400^{\circ} \mathrm{C}$. The TEM samples were stored under dry conditions at room temperature until analyses. According to the $b_{\mathrm{abs}}$ values, the four samples obtained without passing the particles through the TD and one sample obtained after passing the particles through the TD maintained at $400{ }^{\circ} \mathrm{C}$ were selected and analyzed.

To obtain stereoscopic information of particles from 2-D microphotograph, particles were coated with a Pt / Pd alloy at a shadowing angle of $26.6^{\circ}(\arctan 0.5)$, according to the method of Okada (1983). The Pt / Pd coating thickness was about $7 \AA$. The scanned image was processed using image analysis software (Win Roof; Mitani Corp.) to estimate the projected area of the particles. Elemental compositions of individual particles were analyzed using an energy-dispersive $\mathrm{X}$-ray spectrometer (EDS) along with the TEM. The EDS was operated at an accelerating voltage of $120 \mathrm{kV}$. Elemental analyses were performed for $\mathrm{C}, \mathrm{Na}, \mathrm{Mg}, \mathrm{Al}, \mathrm{Si}, \mathrm{P}, \mathrm{S}, \mathrm{Cl}, \mathrm{K}$, $\mathrm{Ca}, \mathrm{Ti}, \mathrm{V}, \mathrm{Cr}, \mathrm{Mn}, \mathrm{Fe}, \mathrm{Ni}, \mathrm{Zn}, \mathrm{Sn}$, and $\mathrm{Pb}$. The X-ray spectrum was obtained using a detector with a counting time of $20 \mathrm{~s}$ per particle. The peak intensities of the elemental compositions in individual particles were quantified from the spectrum after deduction of the background spectrum near the particles. Based on the peak intensity, compositional particle types were classified as sulfate-rich, carbon-rich, sea-saltrich, aged sea-salt-rich, crustal-rich, or others. Carbon-rich particles have the largest $C$ peak. Sulfate-rich particles have the largest S peak and are absent of Na. Sea salt-rich particles have the largest $\mathrm{Na}$ peak or are Na-containing particles having the largest $\mathrm{Cl}$ peak. Aged sea-salt-rich particles are 
Na-containing particles having the largest $\mathrm{S}$ peak. Crustalrich particles have the largest peaks of $\mathrm{Al}, \mathrm{Si}$, or Fe. Particles having peaks other than those above, or not having a detectable peak, were classified as others. In this classification, a spectrum larger than 2 times the standard deviation of the background spectra, which are spectra for non-particle areas measured between each sample analysis, was used as the detectable spectrum of the particles to eliminate background noise effects. However, it should be noted that the standard deviation of the background $\mathrm{C}$ spectra is high because of the use of C-coated collodion film; therefore, there is a possibility that the number of $\mathrm{C}$-rich particles is actually higher than that counted. To overcome this, the ratio of $\mathrm{C}$ to another element before elimination of the noise was utilized as an index of carbon content (Sect. 3.3.2).

\section{Results and discussion}

\subsection{Temporal variation in optical properties}

Figure 2 shows the temporal variations in absorption $\left[b_{\text {abs }}(\lambda)\right]$ and scattering $\left[b_{\text {sca }}(\lambda)\right]$ coefficients and enhancement of light absorptions $\left[E_{\mathrm{abs}}(\lambda)\right]$ observed during 17 April-14 May 2013. Averages of $b_{\text {abs }}(\lambda)$ and $b_{\text {sca }}(\lambda)$ during the entire observation period are listed in Table 1 . The $b_{\text {abs }}(405 \mathrm{~nm})$ and $b_{\text {abs }}(781 \mathrm{~nm})$ at $25^{\circ} \mathrm{C}$ varied from close to 0 to $10 \mathrm{Mm}^{-1}$ and 0 to $5 \mathrm{Mm}^{-1}$, respectively. High $b_{\text {abs }}(\lambda)$ events (higher than $5 \mathrm{Mm}^{-1}$ at $405 \mathrm{~nm}$ ) were observed on 19 , 22, and 27-29 April and on 6, 10, and 13-14 May. The $b_{\text {sca }}$ at $25^{\circ} \mathrm{C}$ was almost synchronous with $b_{\mathrm{abs}}$, but the values were about 10 times larger (Table 1). For sample air that passed through the TD at 300 and $400^{\circ} \mathrm{C}$, averaged $b_{\text {sca }}$ values were, respectively, one-seventh and one-eighth of those at $25^{\circ} \mathrm{C}$ at $405 \mathrm{~nm}$, and one-fourth of those at $25^{\circ} \mathrm{C}$ at $781 \mathrm{~nm}$ (Fig. 2b and d). In contrast, the values of $b_{\mathrm{abs}}(405 \mathrm{~nm})$ and $b_{\mathrm{abs}}$ $(781 \mathrm{~nm})$ at high temperature $\left(300\right.$ and $\left.400^{\circ} \mathrm{C}\right)$ were only slightly different from those at $25^{\circ} \mathrm{C}$ (Fig. 2a and c).

Most of the $E_{\text {abs }}(405 \mathrm{~nm})$ values on 19, 22-23, 26-29 April and 5-6 May were less than 1.0 and also less than the $E_{\mathrm{abs}}(532 \mathrm{~nm})$ and $E_{\mathrm{abs}}(781 \mathrm{~nm})$ values, while the $E_{\mathrm{abs}}(\lambda)$ values on 13-14 May were greater than 1.0 at all wavelengths. Averaged $E_{\mathrm{abs}}(\lambda)$ for the data above the detection limit during the entire observation period are also listed in Table 1. Similar averaged $E_{\text {abs }}(\lambda)$ values between 300 and $400^{\circ} \mathrm{C}$ were obtained at each wavelength. Because brown carbon is considered to absorb light only at shorter visible and UV wavelengths (Andreae and Gelencsér, 2006; Moosmüller et al., 2009), $E_{\text {abs }}(405 \mathrm{~nm})$ was expected to be larger than $E_{\text {abs }}(781 \mathrm{~nm})$ if light absorption by organic materials evaporated at temperatures below 300 or $400^{\circ} \mathrm{C}$ contributed to the total light absorption at $405 \mathrm{~nm}$. However, this study produced the opposite result. This can be explained by the increase of "brownish materials" by heating. Here, the "brownish materials" are defined as the materials which were gener-

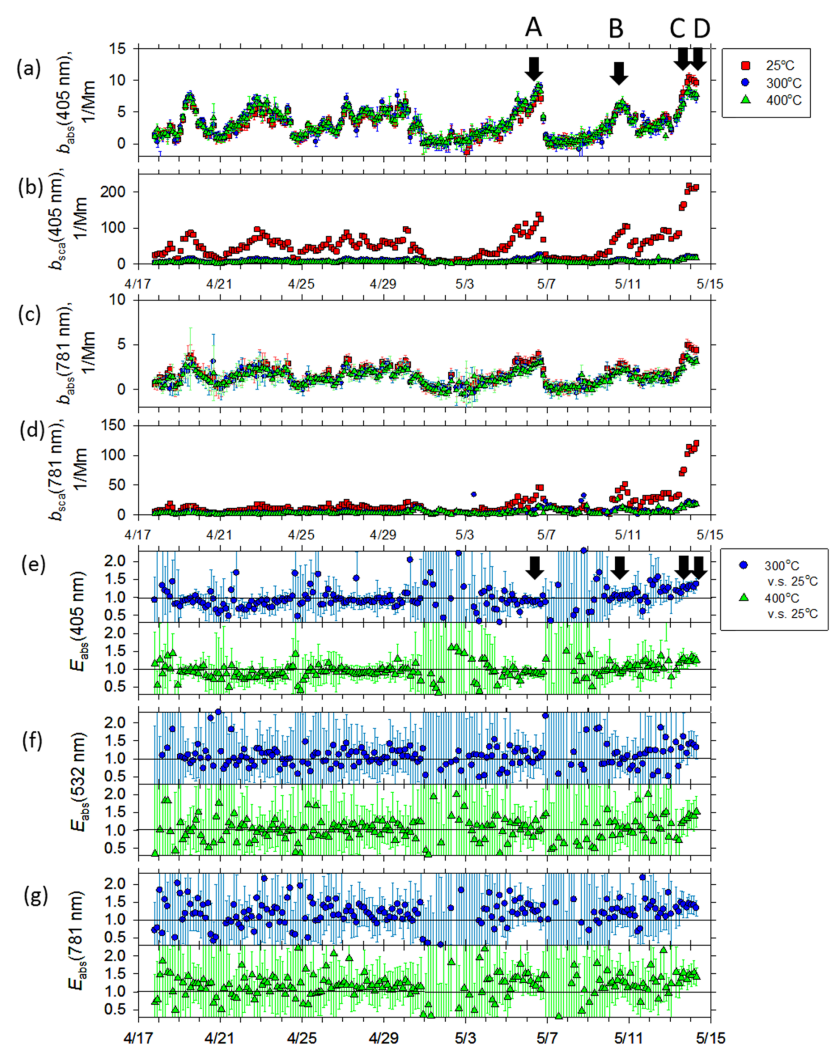

Figure 2. Temporal variations in (a) absorption coefficients at $405 \mathrm{~nm}$ and start times of TEM sampling (A-D with arrows), (b) scattering coefficients at $405 \mathrm{~nm}$, (c) absorption coefficients at $781 \mathrm{~nm}$, (d) scattering coefficients at $781 \mathrm{~nm}$, and (e, f, g) enhancement of light absorption ( $\left.E_{\text {abs }}\right)$ at 405,532 , and $781 \mathrm{~nm}$, respectively. Red, blue, and green symbols in (a-d) represent conditions of 25,300 , and $400^{\circ} \mathrm{C}$, respectively. Blue and green symbols in (eg) represent $E_{\mathrm{abs}}\left[=b_{\mathrm{abs}}\left(\lambda, 25^{\circ} \mathrm{C}\right) / b_{\mathrm{abs}}(\lambda, T)\right]$ with $T=300$ and $400^{\circ} \mathrm{C}$, respectively. The values are $3 \mathrm{~h}$ averaged data.

ated by heating in the TD and had significant light absorption at shorter visible wavelengths in order to distinguish from ambient brown carbon particles.

In this study, as explained in the previous section, $b_{\mathrm{abs}}(\lambda)$ was corrected for the effect of loss and formation of rBC inside the TDs using the mass concentration of $\mathrm{rBC}$ measured by SP2. However, the absorption by brownish materials that was potentially formed in the TDs might not be corrected accurately using this method because of the difference in wavelength dependence of light absorption between $\mathrm{BC}$ and brownish materials. According to the above explanation, $E_{\text {abs }}(405 \mathrm{~nm})$ and $E_{\text {abs }}(532 \mathrm{~nm})$ might have been particularly underestimated due to the absorption by brownish materials formed in the TDs. Because the influence of the formation of brownish materials on $E_{\text {abs }}(781 \mathrm{~nm})$ should be minimal, $E_{\text {abs }}(781 \mathrm{~nm})$ is considered to represent the lensing effect in later discussions.

It should be noted that $E_{\text {abs }}(781 \mathrm{~nm})$ was calculated using Eq. (1) on the assumption that the light-absorbing property 
Table 1. Average values of absorption and scattering coefficients $\left(\mathrm{Mm}^{-1}\right)$ and enhancement of absorption during the observation period ${ }^{\mathrm{a}}$.

\begin{tabular}{lllll}
\hline$\lambda$ & $b_{\text {abs }}(\lambda)$ & $b_{\text {sca }}(\lambda)$ & $E_{\text {abs }}\left(\lambda, 300^{\circ} \mathrm{C}\right)^{\mathrm{b}}$ & $E_{\text {abs }}\left(\lambda, 400^{\circ} \mathrm{C}\right)^{\mathrm{b}}$ \\
\hline $405 \mathrm{~nm}$ & $3.1[1.3-4.6]$ & $51.9[23.5-70.1]$ & $0.98[0.85-1.09]$ & $0.99[0.87-1.06]$ \\
$532 \mathrm{~nm}$ & $2.7[1.2-3.8]$ & - & $1.06[0.90-1.20]$ & $1.06[0.93-1.20]$ \\
$781 \mathrm{~nm}$ & $1.7[0.8-2.4]$ & $16.1[7.3-17.4]$ & $1.22[1.07-1.38]$ & $1.23[1.10-1.35]$ \\
\hline
\end{tabular}

a Values in square brackets show the 25 th-75th percentile range.

b Only the data above the detection limit were used in the calculation.

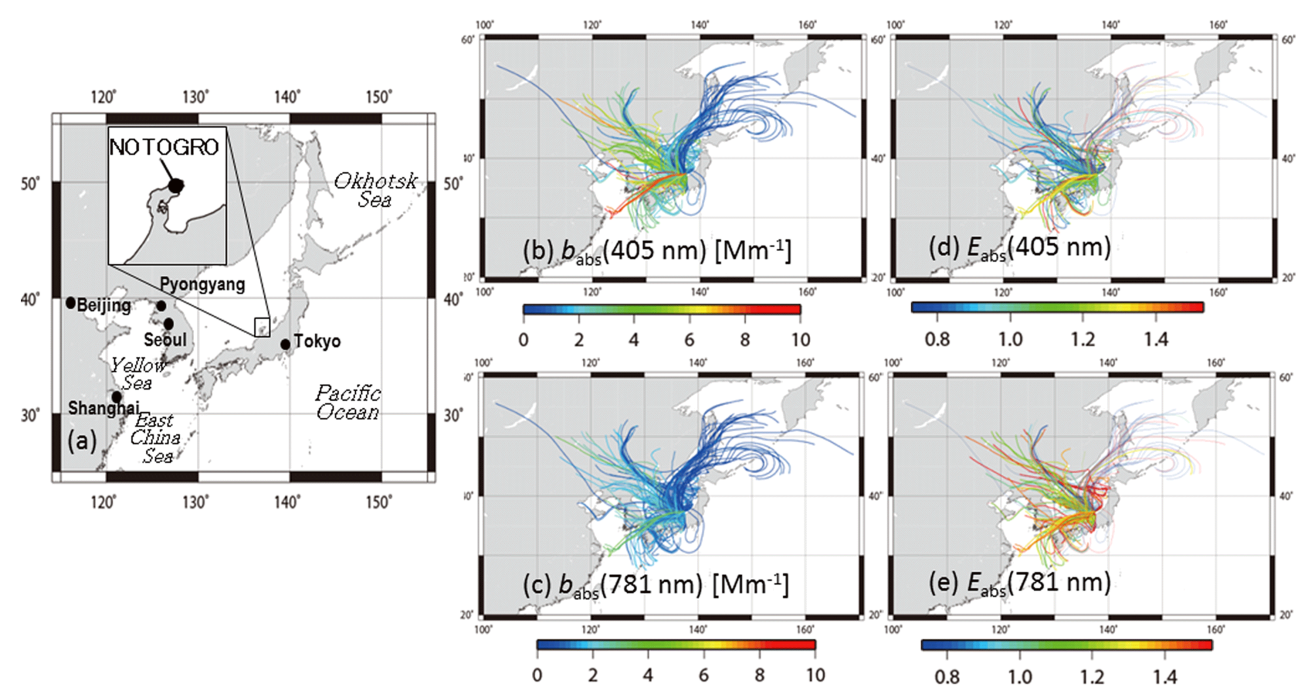

Figure 3. (a) Location of NOTOGRO in Ishikawa, Japan, and (b-e) $72 \mathrm{~h}$ backward air trajectories for air masses reaching the observation site at $500 \mathrm{~m}$ a.s.1. These are colored with $(\mathbf{b}) b_{\mathrm{abs}}(405 \mathrm{~nm})$, (c) $b_{\mathrm{abs}}(781 \mathrm{~nm})$, (d) $E_{\mathrm{abs}}(405 \mathrm{~nm})$, and $(\mathbf{e}) E_{\mathrm{abs}}(781 \mathrm{~nm})$. The trajectories for $E_{\text {abs }}$ calculated from $b_{\text {abs }}$ data below the detection limit are represented as thin lines in (d) and (e).

of ambient $\mathrm{rBC}$ was same with that of $\mathrm{rBC}$ generated in the TD. If mass absorption cross section at $781 \mathrm{~nm}$ for $\mathrm{rBC}$ generated in the TD were different by $50 \%$ compared to that for ambient $\mathrm{rBC}$, the lensing effect could be underestimated or overestimated by $0.05-0.10$, considering $10-20 \%$ of $\mathrm{rBC}$ were generated by heating in the TD (Sect. 2.2).

\subsection{Relations between backward air mass trajectories and optical properties}

Figure 3 presents (a) the location of NOTOGRO and (be) the 3-day backward air trajectories for air masses reaching the observation site. The backward trajectory data were computed using the Hybrid Single-Particle Lagrangian Integrated Trajectory (HYSPLIT 4) model developed by the National Oceanic and Atmospheric Administration (NOAA) Air Resources Laboratory (ARL) (Draxler and Rolph, 2003; Rolph, 2003). The trajectories are colored according to $b_{\mathrm{abs}}$ $(405 \mathrm{~nm})$ and $b_{\text {abs }}(781 \mathrm{~nm})$ and according to $E_{\text {abs }}(405 \mathrm{~nm})$ and $E_{\text {abs }}(781 \mathrm{~nm})$ calculated from $b_{\text {abs }}$ values at 25 and $300^{\circ} \mathrm{C}$. The trajectories for $E_{\mathrm{abs}}$ calculated from $b_{\mathrm{abs}}$ data below the detection limit are presented as thin lines in Fig. 3d and e.
The $b_{\text {abs }}$ tended to be greater in air masses from the East Asian continent and lower in air masses from the north, such as from the Okhotsk Sea. When the greatest $b_{\text {abs }}$ value was observed on the morning of 14 May, the air mass originated from around Shanghai and was transported over the East China Sea. Large amounts of BC and precursors of secondary aerosols are considered to be emitted from the industrial areas facing the Yellow Sea and East China Sea in eastern China (Streets et al., 2003; Bond et al., 2004). Pollution events involving large amount of aerosols have been reported around the industrial areas in eastern China (Gao et al., 2009) and their leeward areas (Takami et al., 2005, 2007).

The $E_{\text {abs }}$ at both 405 and $781 \mathrm{~nm}$ tended to differ according to the origin of the air mass: the $E_{\text {abs }}$ was high (1.31.4 at $405 \mathrm{~nm}$ and $1.3-1.5$ at $781 \mathrm{~nm}$ ) when air mass originated from around Shanghai and was transported over the East China Sea (13-14 May), and was low (<1.0 at $405 \mathrm{~nm}$ and $1.0-1.3$ at $781 \mathrm{~nm}$ ) when the air mass originated from northern China or Siberia and was transported over the northern part of the Korean Peninsula and the Sea of Japan (19, 22, 27 , and 28 April), or from the Sea of Japan or a region of the main island of Japan (22 and 29 April and 6 and 10 May). The $E_{\text {abs }}$ values for the air mass from the Okhotsk Sea were 
not determined because the absorption coefficients were below the detection limit.

\subsection{TEM analyses}

\subsubsection{Physicochemical properties of aerosols}

The four samples collected during high- $b_{\text {abs }}$ events in May were analyzed using TEM. The start times of the sampling are shown with the arrows A-D in Fig. 2a. The details of the samples are listed in Table 2. For all samples, the average $E_{\text {abs }}(405 \mathrm{~nm})$ values were smaller than the average $E_{\text {abs }}$ $(781 \mathrm{~nm})$ values by $0.1-0.4$.

The ratio of $\mathrm{NO}_{x}$ to $\mathrm{NO}_{y}$ has been used as an indicator of photochemical age of air mass (e.g., Cappa et al., 2012). The ratio for samples $\mathrm{A}, \mathrm{B}, \mathrm{C}$, and $\mathrm{D}$ were $0.43,0.67,0.38$, and 0.24 , respectively. The results suggest that the plume ages for samples C and D are greater than those for samples A and B, although quantitative estimation of the plume age is difficult due to the possible contributions of wet and dry depositions of $\mathrm{NO}_{y}$.

Figure 4 portrays the $72 \mathrm{~h}$ horizontal backward trajectories of air parcels for samples A, B, C, and D, starting at $500 \mathrm{~m}$ above sea level at the NOTOGRO site. The trajectories for samples A and B showed that the air masses were transported slowly and reached the observation site over the north coast of the main island of Japan. The air masses for sample C were from northern China and were transported over the Korean Peninsula and the Sea of Japan, while those for sample D were from the Shanghai area and were transported over the East China Sea and the Sea of Japan within $\sim 3$ days. Combining these trajectories with the results of the ratios of $\mathrm{NO}_{x}$ to $\mathrm{NO}_{y}$ indicates that samples $\mathrm{A}$ and $\mathrm{B}$ were likely affected by emissions from the main island of Japan, while samples $\mathrm{C}$ and $\mathrm{D}$ could be considered to be mainly affected by continental outflow.

For samples A, B, and D, 96, 88, and 97\%, respectively, of the mass concentration of non-refractory materials measured by the ACSM consisted of $\mathrm{SO}_{4}^{2-}, \mathrm{NH}_{4}^{+}$, and organics (Table 2). The organic mass ratio for samples A, B, and D were 62,62 , and $24 \%$, respectively. The BC mass concentrations measured by SP2 were 4,3 , and $2 \%$ of the total submicron particle mass (sum of the mass concentrations of $\mathrm{BC}$ and non-refractory materials) for samples $\mathrm{A}, \mathrm{B}$, and $\mathrm{D}$, respectively. The inlet line of the ACSM system was connected to a different line from 12:00 on 12 May to 17:30 on 13 May 2013, and the data for this period are not used in this study.

Figure 5 presents number-based size distributions at 25, 300 , and $400^{\circ} \mathrm{C}$, and the cross-sectional area- and volumebased size distributions at $25^{\circ} \mathrm{C}$ of aerosol particles during samplings A-D, as measured by SMPS. Because use of the SMPS (TSI, model 3696L72) placed downstream of the heating system (shown in Fig. 1) was ended on 13 May, the 8$346 \mathrm{~nm}$ size distribution measured by another SMPS (TSI, model 3936L76) placed downstream of the $\mathrm{PM}_{10}$ inlet is

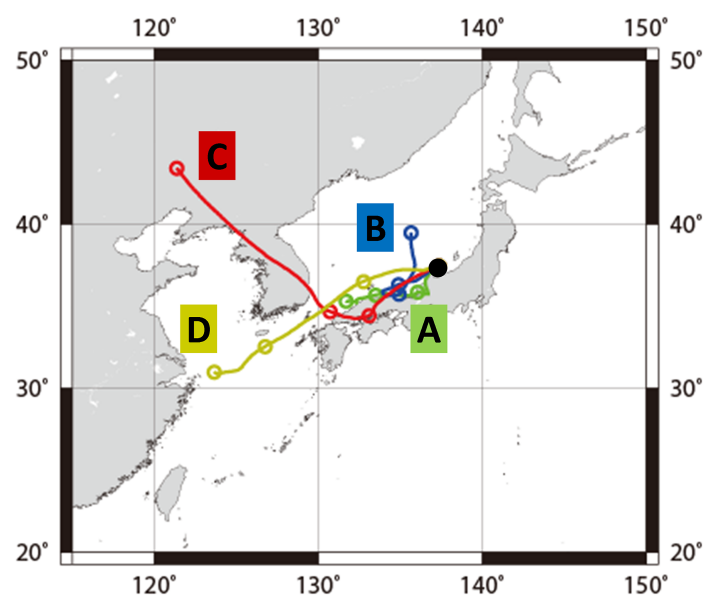

Figure 4. The $72 \mathrm{~h}$ horizontal backward trajectories for air masses reaching the observation site at $500 \mathrm{~m}$ a.s.l. during sampling periods A-D. Open dots along the trajectory represent the position of the air mass every $24 \mathrm{~h}$ backward from the arrival point.

used on 14 May. Number-size distribution at $25^{\circ} \mathrm{C}$ shows that number concentrations were higher in the $<100 \mathrm{~nm}$ fraction for samples A and B, but for samples $\mathrm{C}$ and $\mathrm{D}$ they were higher in the $>100 \mathrm{~nm}$ fraction. The inlet line of the ACSM system was connected to a different line from 12:00 on 12 May to 17:30 on 13 May 2013, and the data for this period are not used in this study. By passing the particle through the TD maintained at 300 or $400^{\circ} \mathrm{C}$, the total particle number concentration decreased by one-fourth to one-half and the distribution had peaks in the $<100 \mathrm{~nm}$ fraction for samples A-C. In contrast, particles with diameters between 100 and $400 \mathrm{~nm}$ mainly contributed to the total cross-sectional area and volume of particles for all samples, and this is considered to contribute mainly to their optical properties.

Figure 6a presents the mass equivalent size distributions of $\mathrm{rBC}$ measured by SP2 for samples A-D together with their log-normal best-fitting curves. The peak diameters were around $200 \mathrm{~nm}$ for all samples and were slightly larger for samples C and D compared to those for samples A and B. Figure $6 \mathrm{~b}$ presents the normalized-count distribution of lag time for $\mathrm{rBC}$ with a mass equivalent diameter of $200 \pm 10 \mathrm{~nm}$. Unfortunately, the coating thickness of $\mathrm{rBC}$ could not be obtained directly by SP2 in this study because of a mechanical issue on a detector to determine absolute position of particles in the laser beam. Instead, the lag time is treated as an index of the mixing states of rBC-containing particles because the scattering signal of the thicker-coated $\mathrm{rBC}$ core is detected before the incandescence signal from the $\mathrm{rBC}$ (Moteki and Kondo, 2007). The bimodal distribution of lag time could be reasonably fitted by combination of two Gaussian functions. The lag-time value of the uncoated fullerene soot particle employed in the calibration was $0.8 \pm 0.5 \mu$ s, indicating that uncoated $\mathrm{BC}$ particles also should be within this range. Therefore, lag-time peaks for $\mathrm{rBC}$ with a diameter of 
Table 2. TEM samples used in this study, and $\mathrm{rBC}, \mathrm{NO}_{x}$, and $\mathrm{NO}_{y}$ concentrations and optical parameters (average values \pm standard deviation) during the sampling periods.

\begin{tabular}{|c|c|c|c|c|c|}
\hline \multicolumn{6}{|l|}{ TEM sample } \\
\hline \multicolumn{2}{|l|}{ Date } & 6 May & 10 May & 13 May & 14 May \\
\hline \multicolumn{2}{|c|}{ Starting local time } & 09:10 & 10:09 & $16: 00$ & $08: 29$ \\
\hline \multicolumn{2}{|c|}{ Collection time } & $7 \mathrm{~min}$ & $7 \mathrm{~min}$ & $10 \mathrm{~min}$ & $6 \mathrm{~min}$ \\
\hline \multicolumn{2}{|c|}{ Analyzed particle number } & 586 & 296 & 226 & 412 \\
\hline \multicolumn{6}{|l|}{ SP2 } \\
\hline rBC mass & {$\left[\mathrm{ng} \mathrm{m}^{-3}\right]$} & $424 \pm 11$ & $403 \pm 30$ & $520 \pm 28$ & $597 \pm 21$ \\
\hline \multicolumn{6}{|l|}{ ACSM } \\
\hline Org & {$\left[\mu \mathrm{g} \mathrm{m}^{-3}\right]$} & 6.20 & 8.81 & - & 7.64 \\
\hline $\mathrm{NH}_{4}^{+}$ & {$\left[\mu \mathrm{g} \mathrm{m}^{-3}\right]$} & 1.45 & 1.52 & - & 5.87 \\
\hline $\mathrm{SO}_{4}^{2-}$ & {$\left[\mu \mathrm{g} \mathrm{m}^{-3}\right]$} & 2.02 & 2.10 & - & 17.46 \\
\hline $\mathrm{NO}_{3}^{-}$ & {$\left[\mu \mathrm{g} \mathrm{m}^{-3}\right]$} & 0.34 & 1.72 & - & 1.05 \\
\hline $\mathrm{Cl}^{-}$ & {$\left[\mu \mathrm{g} \mathrm{m}^{-3}\right]$} & 0.03 & $\mathrm{nd}^{*}$ & - & $\mathrm{nd}^{*}$ \\
\hline Total mass & {$\left[\mu \mathrm{g} \mathrm{m}^{-3}\right]$} & 10.05 & 14.15 & - & 32.01 \\
\hline \multicolumn{6}{|l|}{$\mathrm{NO}_{x}, \mathrm{NO}_{y}$} \\
\hline $\mathrm{NO}_{x}$ & [ppbv] & $1.6 \pm 0.9$ & $3.7 \pm 1.7$ & $1.3 \pm 0.1$ & $1.0 \pm 0.1$ \\
\hline $\mathrm{NO}_{y}$ & [ppbv] & $3.4 \pm 0.9$ & $5.3 \pm 1.5$ & $3.5 \pm 0.2$ & $4.0 \pm 0.2$ \\
\hline$\left[\mathrm{NO}_{x}\right] /\left[\mathrm{NO}_{y}\right]$ & & $0.43 \pm 0.12$ & $0.67 \pm 0.11$ & $0.38 \pm 0.03$ & $0.24 \pm 0.03$ \\
\hline \multicolumn{6}{|l|}{ PASS-3 } \\
\hline \multirow[t]{3}{*}{$b_{\mathrm{abs}} \quad\left[\mathrm{Mm}^{-1}\right]$} & $405 \mathrm{~nm}$ & $6.3 \pm 0.6$ & $5.6 \pm 1.2$ & $7.9 \pm 0.8$ & $9.4 \pm 0.2$ \\
\hline & $532 \mathrm{~nm}$ & $4.6 \pm 2.1$ & $4.4 \pm 0.6$ & $6.0 \pm 0.6$ & $8.2 \pm 0.4$ \\
\hline & $781 \mathrm{~nm}$ & $2.8 \pm 0.3$ & $1.9 \pm 0.6$ & $3.5 \pm 0.6$ & $4.7 \pm 0.2$ \\
\hline \multirow[t]{2}{*}{$b_{\text {sca }} \quad\left[\mathrm{Mm}^{-1}\right]$} & $405 \mathrm{~nm}$ & $99.8 \pm 7.4$ & $79.0 \pm 4.1$ & $155.8 \pm 5.0$ & $215.1 \pm 1.9$ \\
\hline & $781 \mathrm{~nm}$ & $27.3 \pm 4.7$ & $35.6 \pm 17.3$ & $69.2 \pm 2.9$ & $120.7 \pm 2.5$ \\
\hline \multirow[t]{3}{*}{$E_{\text {abs }}\left(300^{\circ} \mathrm{C}\right)$} & $405 \mathrm{~nm}$ & $0.88 \pm 0.12$ & $0.97 \pm 0.26$ & $1.33 \pm 0.21$ & $1.35 \pm 0.06$ \\
\hline & $532 \mathrm{~nm}$ & $1.31 \pm 0.60$ & $1.09 \pm 0.40$ & $1.42 \pm 0.24$ & $1.18 \pm 0.20$ \\
\hline & $781 \mathrm{~nm}$ & $1.25 \pm 0.37$ & $1.13 \pm 0.49$ & $1.44 \pm 0.23$ & $1.42 \pm 0.18$ \\
\hline \multirow[t]{3}{*}{$E_{\mathrm{abs}}\left(400^{\circ} \mathrm{C}\right)$} & $405 \mathrm{~nm}$ & $0.88 \pm 0.12$ & $1.03 \pm 0.25$ & $1.22 \pm 0.13$ & $1.31 \pm 0.06$ \\
\hline & $532 \mathrm{~nm}$ & $1.05 \pm 0.15$ & $1.13 \pm 0.36$ & $1.10 \pm 0.12$ & $1.43 \pm 0.38$ \\
\hline & $781 \mathrm{~nm}$ & $1.26 \pm 0.29$ & $1.24 \pm 0.60$ & $1.58 \pm 0.20$ & $1.52 \pm 0.19$ \\
\hline
\end{tabular}

* nd: not detected

$200 \pm 10 \mathrm{~nm}$ in the range $0.6-1.0$ and $2.3-2.6 \mu$ s in Fig. $6 \mathrm{~b}$ should be non/less-coated and thickly coated, respectively. The fractions of thickly coated rBC were $73,65,81$, and $88 \%$ for samples A, B, C, and D, respectively, while the peak lag times of non/less-coated $\mathrm{rBC}$ and thickly coated $\mathrm{rBC}$ were similar for all samples. The greater count fraction of thickly coated $\mathrm{BC}$ for samples $\mathrm{C}$ and $\mathrm{D}$ compared to those for samples A and B was consistent with the expectation based on the trajectories of the air masses: samples $\mathrm{C}$ and $\mathrm{D}$ were considered to be influenced mainly by continental outflow and samples A and B were likely influenced by emissions from the main island of Japan.

\subsubsection{Morphological types and mixing states}

Figure 7 shows examples of electron microphotographs, at the same magnification, before and after EDS analysis of samples A and D. Most of the particles in all samples had a rounded shape or were clustered into ball shapes. The round particles and spherical portions of clustered particles in sample A were smaller than those of sample D. Comparing particles before and after EDS, a large particle mass was evaporated or sublimated due to beam damage by the high-density electron beam, while some chain-shaped residues (shown by black triangles in Fig. 7a' and b'), which could be characterized as soot, were often found in the particles after EDS. In sample A, non-soot residues were also found in most particles after EDS. This non-soot residue mostly showed a weak contrast against the background collodion film, such as the 
(a) 130506
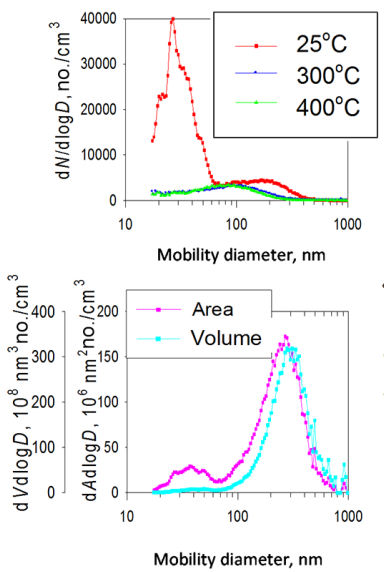

(b) 130510
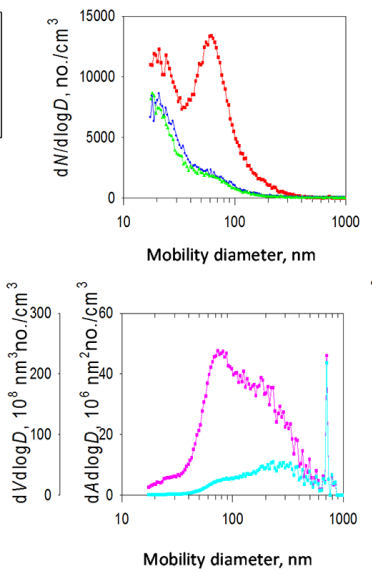

(c) 130513
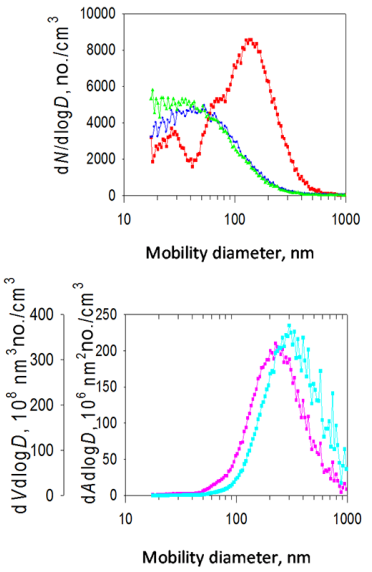

(d) 130514
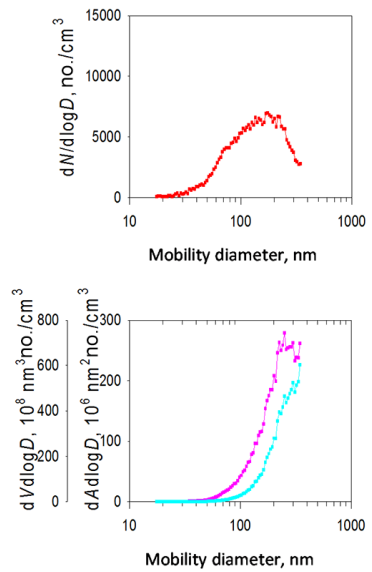

Figure 5. Number- (upper panels), cross-section-area-, and volume-based (lower panels) size distributions of aerosol particles during the sampling of samples A-D, as measured by SMPS. Red lines in the upper panels represent the number-based size distributions for particles measured without passage through the TD, while blue and green lines represent those for particles measured after passage through the TD maintained at 300 and $400^{\circ} \mathrm{C}$, respectively.

materials shown by white triangles in Fig. 7a'. A fraction of soot-like particles coexisted with the weakly contrasting residues. Particles of samples $\mathrm{B}$ and $\mathrm{C}$ resembled those of sample A and D, respectively.

According to the methods used by Ueda et al. (2011), the particles were classified into seven types based on their morphological features, as presented in Fig. 8. The pie chart for each type (Fig. 8) indicates the number fraction of particles for each compositional type based on EDS analysis. The number below the pie graph is the number of particles in each type. Detailed information on the classification and features of each morphological type and estimation of volumeequivalent diameter is described in the Supplement (S2).

For type 2, 3, 4, and 5 particles, EDS analysis indicates that most were composed mainly of sulfate. However, some of them also contained carbon and sulfur, and the mixed ratio of carbon in the particle differed between particle types. The averaged peak intensity $\mathrm{C}$ to $\mathrm{S}$ ratio for sulfate-rich particles was $0.45,0.13,0.88$, and 0.33 for types $2,3,4$, and 5 , respectively. This result suggests that coccoid sulfate (type 3) was less mixed with organic matter, while dome-like sulfate (type 4) was mixed with a larger amount of carbon.

The mixing states of particles were classified by comparing particle shape and morphology before and after irradiation by the intense electron beam of the EDS analysis. Some materials, such as ammonium sulfate and sulfuric acid, evaporate or sublimate due to irradiation by the intense electron beam, whereas non-volatile materials, including soot, sea salt, and crustal particles, remain on the film after irradiation (e.g., Li et al., 2003, 2010; Pósfai et al., 2003; Adachi et al., 2014). The types of mixing states are shown in Fig. 9. Detailed information on the classification of mixing states is described in the Supplement (S3). Based on the EDS anal- ysis, type a particles are composed mainly of carbon and silicate. Type b particles were mostly classified as sulfaterich, sea-salt-rich, or aged sea-salt-rich. For the sulfate-rich type $b$ particles, the $\mathrm{C}$ to $\mathrm{S}$ ratios in the peak intensities were relatively high (0.99 on average), suggesting that they also contained a large amount of carbonaceous material. The majority of the type $\mathrm{c}, \mathrm{d}$, e, and $\mathrm{f}$ particles were classified as sulfate-rich particles. The averaged $\mathrm{C}$ to $\mathrm{S}$ ratios in the peak intensities for sulfate-rich particles were $0.40,0.45,0.71$, and 0.10 for types c, d, e, and f, respectively; type e particles contained relatively large amounts of carbon, whereas type f particles were composed mostly of sulfate. Similar particles to those of type e were also found, and regarded as organics, during observation of the Chinese continental outflow (Li et al., 2013).

Figure 10a and b shows size-segregated number proportions of the mixing states and morphological types of the particles in samples A-D on the basis of the classification in Figs. 9 and 8, respectively. The mixing states had two patterns: (1) a combination of type c (mixed particles of soot and volatile) and type e (semi-volatile) particles, as found in samples A and B; and (2) a combination of type c and type $\mathrm{f}$ (volatile) particles, as found in samples $\mathrm{C}$ and D. Comparing with the chemical compositions measured by ACSM, the proportion of type e particles to type f particles was higher in samples collected when the mass ratio of organics was relatively high. This corresponded with the ratio of $\mathrm{C}$ to $\mathrm{S}$ by EDS analysis for type e and $\mathrm{f}$ particles. The number proportion of soot-containing particles (types a and c) was about $10-50 \%$ at each size range. Most soot was found as mixed particles with volatile materials. Morphological types of particles in all the samples (Fig. 10b) were mainly of type 2 (spherical) in the smaller size range and type 5 (clustered) 


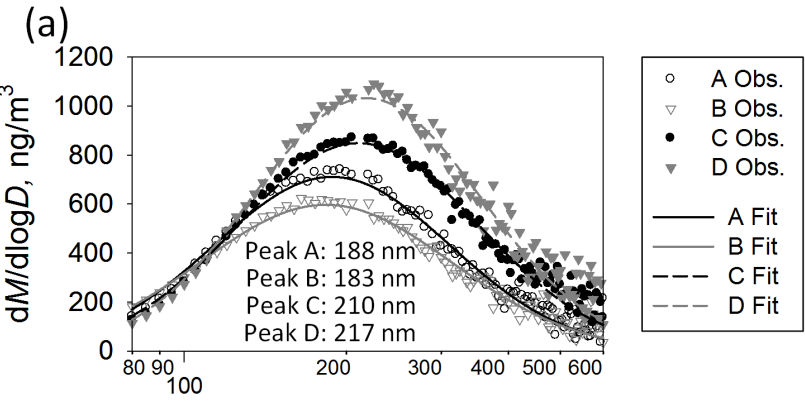

(b)
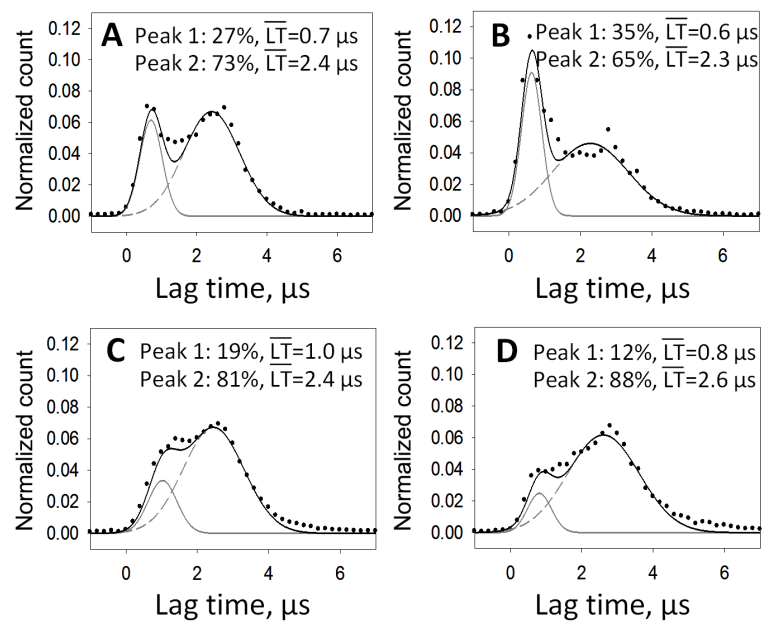

\begin{tabular}{|lll|}
\hline Obs. & & Fit (peak 1) \\
- Fit (peak 1+2) & --- & Fit (peak 2) \\
\hline
\end{tabular}

Figure 6. (a) Mass-based size distributions of rBC with log-normal best-fitting curves and (b) normalized-count distribution of lag time of the incandescent-light signal from the scattering signal for $\mathrm{rBC}$ with a mass equivalent diameter of $200 \mathrm{~nm}$, obtained using the SP2 for samples A-D with best-fit curves assuming the combination of two Gaussian functions. LT represents averaged lag time.

in the larger size range. Compared to samples A and B, the fraction of type 2 particles tended to be higher for samples $\mathrm{C}$ and $\mathrm{D}(0.3-0.6 \mu \mathrm{m})$.

Relatively large spherical and clustered sulfate-rich particles were found in aged air masses (samples C and D), as discussed in Sect. 3.3.1. Similar spherical and clustered sulfate-rich particles were simultaneously observed in the Asian outflow at Cape Hedo (Ueda et al., 2011). Using a simple numerical model and meteorological conditions along the backward trajectories, Ueda et al. (2011) demonstrated that the presence of clustered particles under dry conditions was explained by coagulation processes over several days in polluted conditions. In the present study, spherical particles were simultaneously observed with clustered particles. In addition, the relative humidity along the backward air mass trajectories, which were computed using the HYSPLIT model, was
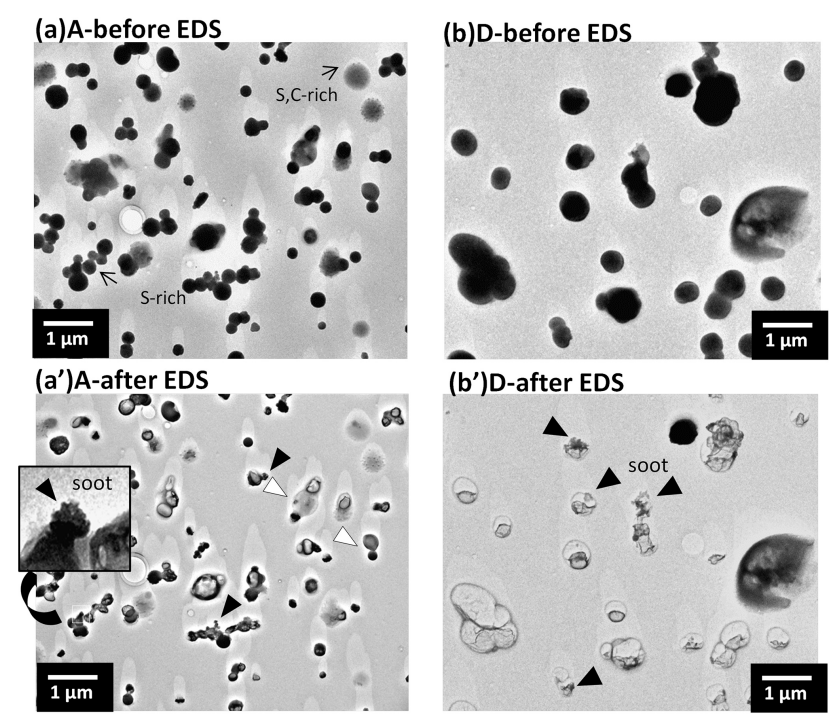

Figure 7. Electron microphotographs before and after EDS analysis of samples (a, a') A and (b, b') D. Soot is shown by black triangles in (a') and (b'). Non-soot residues are shown by white triangles.

lower than the deliquescence humidity of ammonium sulfate ( $80 \%$ ) for about 1 day for sample A and about 2 days for samples B, C, and D before arrival at the site. Therefore, clustered particles would have been formed by coagulation of spherical particles under dry conditions. The differences of spherical particle (and spherical parts of clustered particle) sizes among samples A-D might be attributed to the different sources and/or aging processes through the condensation of gaseous molecules.

Figure 10c shows size-segregated number proportions of the morphological types of soot-containing particles (i.e., types a and c) before EDS analysis. Number proportions for soot-containing particles show a similar tendency to those for all particles in Fig. 10b. This indicates that the morphology of a large portion of soot-containing particles reflected the shape of the coating materials, while a portion of the sootcontaining particles has a soot-aggregated shape (type 1) in samples A and B. The presence of the non/less-coated soot particles in samples A and B is consistent with the results obtained by the SP2 (Fig. 6).

\subsubsection{Internal mixing states and shape factors for soot-containing particles}

The controlling factors of the lensing effect of a sootcontaining particle include coating thickness, morphology and position of the soot, and composition of the coating materials. In this study, the shape factors for soot-containing particles (i.e., types a and c) were estimated by electron micrograph before and after irradiation with an intense electron beam. 


\section{Morphological types}

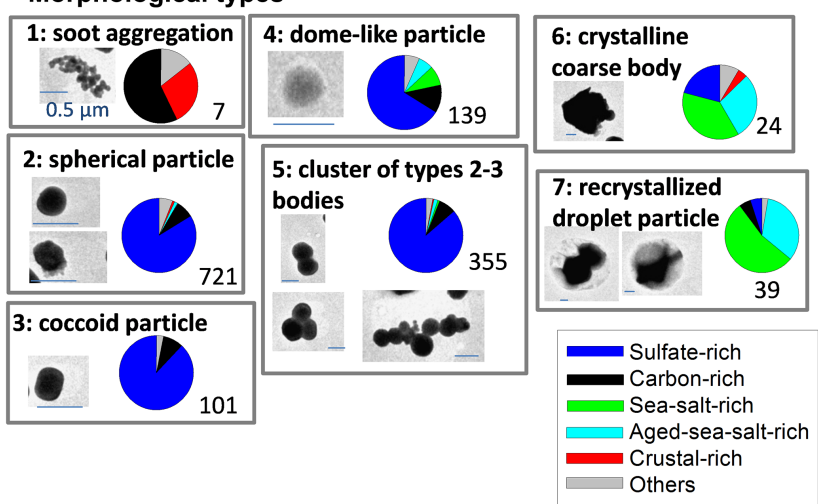

Figure 8. Morphological classification of particle types 1-7. Horizontal bars in the photographs represent a length of $0.5 \mu \mathrm{m}$. The pie chart in each morphological type represents the number fraction of compositional types classified based on the EDS analysis. The number below the pie chart represents the number of analyzed particles.

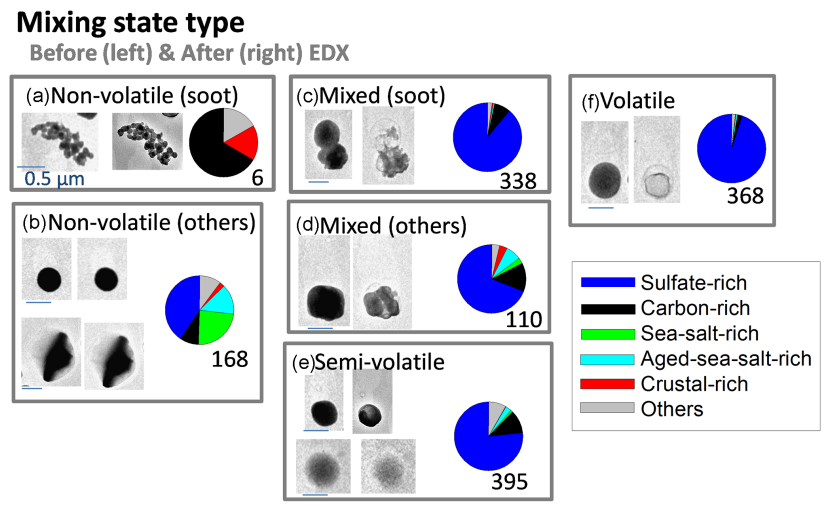

Figure 9. Classification of mixing states based on the comparison of electron micrographs for individual particles before (left) and after (right) irradiation by an electron beam: type a, non-volatile soot particles; type b, non-volatile particles except soot; type c, mixed particles of volatile material and non-volatile soot aggregate; type $\mathrm{d}$, mixed particles of volatile material and non-volatile core without a soot-like shape; type e, semi-volatile particles; and type f, volatile particles. The pie chart in each mixing state type a-f represents the number fraction of compositional types determined by EDS analysis.

Table 3 lists average and 25th and 75th percentile values of parameters of the soot-containing particles (number, particle and soot diameter $\left(d_{\mathrm{p}}, d_{\mathrm{s}}\right)$, volume fraction and relative position of soot $\left(\mathrm{VF}_{\mathrm{s}}, \mathrm{RP}\right)$, circularity factor $(\mathrm{CF})$ and aspect ratio (AR)) for each sample. Details of image analysis and estimation of these parameters are described in the Supplement (S4). The soot diameters $d_{\mathrm{s}}$ were $0.2-0.3$ and $0.2-$ $0.4 \mu \mathrm{m}$ for particles with $d_{\mathrm{p}}$ of $\leq 0.6$ and $>0.6 \mu \mathrm{m}$, respectively. The $d_{\mathrm{s}}$ values are roughly consistent with the diameter of $\mathrm{rBC}$ determined using SP2 (Fig. 6a). The $\mathrm{VF}_{\mathrm{s}}$ were 21-

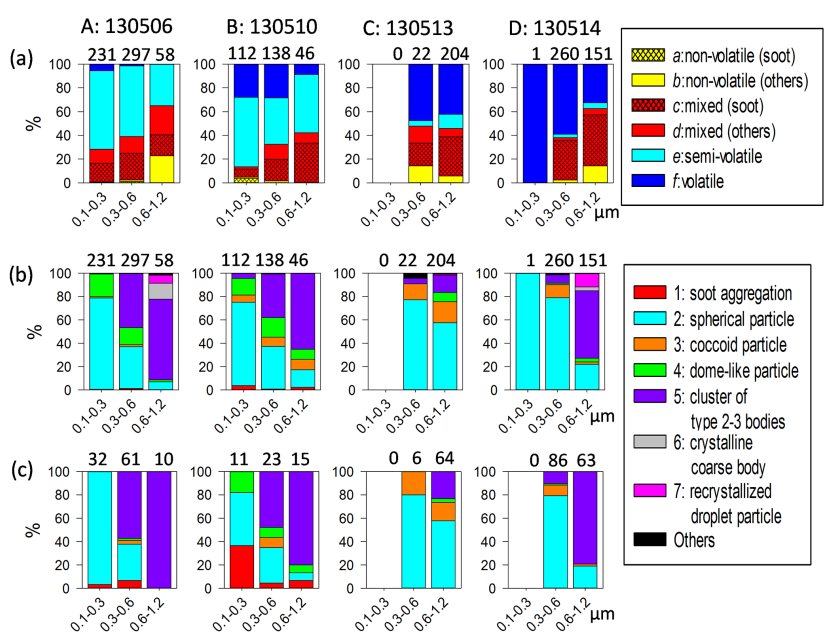

Figure 10. Size-segregated number proportions of (a) mixing state particle types on the basis of the classification in Fig. 9, (b) morphological particle types on the basis of the classification in Fig. 8 and (c) morphological particle types of soot-containing particles for samples A-D. The numbers above the columns show the number of particles observed.

$50 \%$ and $\sim 10 \%$ for particles with $d_{\mathrm{p}}$ of $<0.6$ and $>0.6 \mu \mathrm{m}$, respectively. The $\mathrm{VF}_{\mathrm{S}}$ values indicate that a large portion of the soot-containing particles were mixed with other materials. Although no significant differences in $\mathrm{VF}_{\mathrm{S}}$ values among the samples were observed for particles with $d_{\mathrm{p}}$ of $>0.6 \mu \mathrm{m}$, the $\mathrm{VF}_{\mathrm{s}}$ values for samples $\mathrm{A}$ and $\mathrm{B}$ were higher than those for samples $\mathrm{C}$ and $\mathrm{D}$ for particles with $d_{\mathrm{p}}$ of $<0.6 \mu \mathrm{m}$, likely due to the presence of the non/less-coated soot particles in samples A and B (as discussed in Sect. 3.3.2). Low values of $\mathrm{VF}_{\mathrm{S}}$ were also reported by observational studies at background and remote sites: for example, the average values (8$28 \%$ ) of the soot volume fraction for $0.15-0.8 \mu \mathrm{m}$ particles at an urban background site in Mainz, Germany (Vester et al., 2007), and median value (15\%) of the soot volume fraction for $0.05-0.3 \mu \mathrm{m}$ particles in Mexico City (Adachi and Buseck, 2008) and median values ( $<20 \%$ for $0.2-0.4 \mu \mathrm{m}$ and $<10 \%$ for $0.4-0.7 \mu \mathrm{m})$ of the insoluble soot volume fraction in Cape Hedo (Ueda et al., 2011).

The $\mathrm{CF}$ and $\mathrm{AR}$ represent shape factors. The averaged $\mathrm{CF}$ and $A R$ values of samples $C$ and $D$ were near $1(C F>0.80$ and $A R<1.3$ ) for all size ranges, suggesting that a large fraction of the particles were near-spherical. Small $\mathrm{CF}$ values $(<0.4)$ were observed for particles with $d_{\mathrm{p}}$ of $>0.6 \mu \mathrm{m}$ in samples A and B, likely due to the clustered morphology of the larger soot-containing particles (type 5, in Fig. 10c).

The RP is an indicator of soot position in the particle. The averaged RP values were $0.4-0.6$ and $0.6-0.9$ for $<0.6$ and $>0.6 \mu \mathrm{m}$ particles, respectively. These values indicate that most of the soot was inside the sphere-equivalent diameter but not at the center of the particle. Our averaged RP values were almost equal to the average values (0.54) of soot parti- 
Table 3. Parameters of the soot-containing particles of TEM samples*.

\begin{tabular}{rllllllllll}
\hline ID & & $\begin{array}{l}\text { Number of } \\
\text { soot particles }\end{array}$ & $\begin{array}{l}\text { Particle diameter, } \\
d_{\mathrm{p}},[\mu \mathrm{m}]\end{array}$ & $\begin{array}{l}\text { Soot diameter, } \\
d_{\mathrm{s}},[\mu \mathrm{m}]\end{array}$ & $\begin{array}{l}\text { Volume fraction, } \\
\text { of soot } \mathrm{VF}_{\mathrm{s}},[\%]\end{array}$ & $\begin{array}{l}\text { Relative position, } \\
\text { of soot RP }\end{array}$ & $\begin{array}{l}\text { Circularity, } \\
\text { factor CF }\end{array}$ & $\begin{array}{l}\text { Aspect ratio, } \\
\mathrm{AR}\end{array}$ \\
\hline $\mathrm{A}$ & $<0.6 \mu \mathrm{m}$ & 99 & 0.36 & {$[0.26-0.45]$} & $0.22[0.16-0.25]$ & 33 & {$[10-50]$} & $0.55[0.30-0.74]$ & $0.73[0.59-0.93]$ & $1.4[1.1-1.6]$ \\
& $>0.6 \mu \mathrm{m}$ & 10 & 0.83 & {$[0.67-0.83]$} & $0.36[0.28-042]$ & 11 & {$[6-14]$} & $0.89[0.75-1.02]$ & $0.34[0.26-0.40]$ & $2.1[1.8-2.4]$ \\
\hline $\mathrm{B}$ & $<0.6 \mu \mathrm{m}$ & 33 & 0.36 & {$[0.26-0.47]$} & $0.20[0.15-0.24]$ & 50 & {$[7-55]$} & $0.48[0.29-0.68]$ & $0.60[0.52-0.73]$ & $1.4[1.2-1.5]$ \\
& $>0.6 \mu \mathrm{m}$ & 18 & 0.89 & {$[0.73-1.07]$} & $0.37[0.21-0.55]$ & 13 & {$[2-16]$} & $0.61[0.42-0.79]$ & $0.39[0.21-0.56]$ & $1.4[1.2-1.5]$ \\
\hline $\mathrm{C}$ & $<0.6 \mu \mathrm{m}$ & 6 & 0.58 & {$[0.57-0.59]$} & $0.32[0.22-0.40]$ & 21 & {$[5-31]$} & $0.42[0.28-0.58]$ & $0.86[0.84-0.88]$ & $1.2[1.1-1.2]$ \\
& $>0.6 \mu \mathrm{m}$ & 75 & 0.92 & {$[0.73-1.04]$} & $0.33[0.22-0.37]$ & 9 & {$[2-10]$} & $0.44[0.24-0.64]$ & $0.81[0.75-0.92]$ & $1.2[1.1-1.4]$ \\
\hline $\mathrm{D}$ & $<0.6 \mu \mathrm{m}$ & 86 & 0.47 & {$[0.42-0.51]$} & $0.23[0.17-0.30]$ & 22 & {$[5-27]$} & $0.55[0.25-0.66]$ & $0.89[0.87-0.94]$ & $1.1[1.0-1.2]$ \\
& $>0.6 \mu \mathrm{m}$ & 80 & 0.87 & {$[0.71-1.02]$} & $0.28[0.14-0.35]$ & 10 & {$[1-12]$} & $0.63[0.38-0.87]$ & $0.80[0.70-0.92]$ & $1.3[1.1-1.5]$ \\
\hline
\end{tabular}

* Values in square brackets show the 25 th-75th percentile values.

Table 4. Number fraction of mixing type of soot for soot-containing particles [\%].

\begin{tabular}{lllll}
\hline ID & & Type a & \multicolumn{2}{c}{ Type c } \\
\cline { 3 - 5 } & & \multicolumn{3}{c}{$\begin{array}{l}\text { Attached/partly } \\
\text { embedded }\end{array}$} \\
coated \\
A & $<0.6 \mu \mathrm{m}$ & 9 & 29 & 62 \\
& $>0.6 \mu \mathrm{m}$ & 0 & 70 & 30 \\
$\mathrm{~B}$ & $<0.6 \mu \mathrm{m}$ & 12 & 33 & 55 \\
& $>0.6 \mu \mathrm{m}$ & 0 & 61 & 39 \\
$\mathrm{C}$ & $<0.6 \mu \mathrm{m}$ & 0 & 0 & 100 \\
& $>0.6 \mu \mathrm{m}$ & 0 & 17 & 83 \\
$\mathrm{D}$ & $<0.6 \mu \mathrm{m}$ & 0 & 5 & 95 \\
& $>0.6 \mu \mathrm{m}$ & 0 & 10 & 90 \\
\hline
\end{tabular}

cle position for $0.05-0.3 \mu \mathrm{m}$ particles in Mexico City (Adachi et al., 2010). It should be noted that the RP value was estimated with reference to the sphere-equivalent diameter in our method. Therefore, the RP values for particles with an irregular shape can be less than 1 even if soot is attached/partly embedded to/in other materials.

Internal mixing states of the soot-containing particles were also classified, directly from the microphotograph, into three types: type a (non/less coated soot), an attached/partly embedded type, and a coated type (Table 4). Particles were classified to the attached/partly embedded type if at least part of the soot in a type $\mathrm{c}$ particle was apparent in the microphotograph before EDS analysis; otherwise, the particle was classified as the coated type. For samples A and B, the number fraction of attached/partly embedded soot was about $30 \%$ for $<0.6 \mu \mathrm{m}$ particles and $60-70 \%$ for $>0.6 \mu \mathrm{m}$ particles. For samples $\mathrm{C}$ and $\mathrm{D}$, most of the soot (> $83 \%$ ) was classified as the coated type. Soot-containing particles in samples A and B had more irregular shapes than those in samples C and $\mathrm{D}$, although no clear difference in averaged RP values among the samples was found. These results suggested that the soot in samples A and B would not be thickly coated compared to that in samples $C$ and D. Several observational studies of soot-containing particles using microscopy also found some attached/partly embedded soot on/in sulfate-rich particles (Johnson et al., 2005; Shi et al., 2008; Adachi and Buseck, 2013).

\subsection{Comparison of optical properties with mixing states and morphological features}

As mentioned in Sect. 3.1, the $E_{\text {abs }}$ values tended to be smaller at shorter wavelengths, possibly due to the formation of brownish materials in the TDs maintained at 300 or $400^{\circ} \mathrm{C}$. In this study, several samples for morphological analysis were collected after passing the particles through the TD maintained at $400^{\circ} \mathrm{C}$. Figure 11 shows an example electron micrograph of such particles. These were sampled just after the collection of sample A on 6 May, when a small $E_{\text {abs }}$ $(405 \mathrm{~nm})$ value $(0.88)$ was observed (Table 2). Based on EDS analysis, some carbon-rich particles were found. The morphologies of the carbon-rich particles not only had a chainlike shape but were also spherical. These particles were not evaporated during irradiation by the high-density electron beam of the EDS analysis. The spherical particle features (i.e., non-volatile, spherical, and carbon-rich) were similar to tar balls, which originate in biomass burning (Pósfai et al., 2003, 2004; Alexander et al., 2008; Adachi and Buseck, 2011). Alexander et al. (2008) quantified the optical properties of similar amorphous carbon sphere particles in the East Asia-Pacific outflow using the electron energy-loss spectrum in TEM, and indicated that these particles have strong light absorption, with mean refractive indices of $1.67-0.27 i$ at $550 \mathrm{~nm}$. Although these carbon-rich, spherical, non-volatile particles were rare in our samples collected without passing the particles through the TD, a large number of particles in samples A and B had non-volatile residues after EDS analysis (type e, in Fig. 10a). Therefore, the spherical, carbonrich particles might be formed by heating, probably due to the incomplete charring of organic compounds, and could be brown in color. 


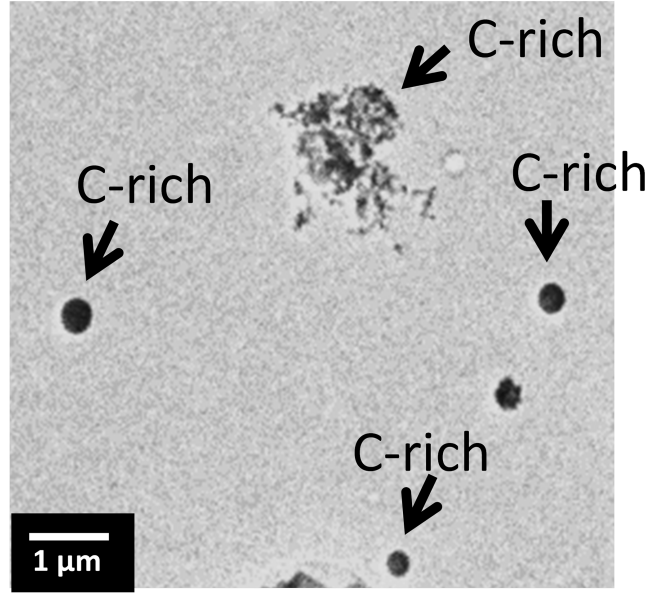

Figure 11. Photographs of an aerosol sample after passage through the TD at $400{ }^{\circ} \mathrm{C}$ sampled for 10 min from 09:38 on 6 May (LT).

In contrast, the formation of brownish materials was not observed in our previous study at an urban area in Nagoya, although the same procedure was used to determine the wavelength-dependent $E_{\text {abs }}$ values (Nakayama et al., 2014). During the observations at Nagoya in August, most of the heated particles were found to be non-spherical (based on the effective density distribution measurements; Nakayama et al., 2014). Differences in the source and degree of aging of carbonaceous particles may contribute to the observed difference in the wavelength dependence of $E_{\mathrm{abs}}$. Our results suggest that attention needs to be paid when a TD is used to estimate the contributions of the lensing effect and brown carbon, especially for particles in aged air masses.

In this study, to avoid the possible contributions of the formation of brownish particles in the TD, $E_{\text {abs }}(781 \mathrm{~nm})$ is used for discussion of the lensing effect. The average $E_{\mathrm{abs}}$ $(781 \mathrm{~nm})$ values observed in this study (1.22 and 1.23 at 300 and $400{ }^{\circ} \mathrm{C}$, respectively, Table 1) were larger than the values reported by Cappa et al. (2012) around large cities in California during early summer (on average 1.06 at $532 \mathrm{~nm}$ ) and by Nakayama et al. (2014) in an urban area at Nagoya, Japan, during August (on average 1.10 at $781 \mathrm{~nm}$ ), likely because relatively aged particles were observed in this study. Very recently, Liu et al. (2015) reported the average $E_{\text {abs }}(781 \mathrm{~nm})$ of 1.4 for BC particles emitted from fossil fuel and residential burning sources in winter at a rural site, Detling $(45 \mathrm{~km}$ away from London), in the UK. The average $E_{\text {abs }}(781 \mathrm{~nm})$ value obtained in the present study is slightly lower than the value reported by Liu et al. (2015).

Most of the soot-containing particles in all the samples under high absorption coefficient conditions were internally mixed with a large amount ( $>50 \%$ of particle volume) of other materials (Table 3). Previous models based on Mie theory and assuming a core-shell (the BC core and coating materials) shape suggested $E_{\text {abs }}$ values larger than 1.5 when particles had a heavy coating (Bond et al., 2006). The av- erage $E_{\text {abs }}$ value observed in this study was still smaller than the estimation assuming core-shell morphology. Adachi et al. (2010) estimated the lensing effect of irregularly shaped particles and those with an assumed core-shell shape, and reported that the difference in the calculated absorption was related to the position of soot in the particle and the fractal dimension. Based on their results, absorption of sootcontaining particles with our averaged RP values (0.4-0.9) could be about 10-25\% smaller than the value estimated assuming core-shell morphology. The position of soot in the particle may contribute to the difference between observation and estimation, as previously suggested by Cappa et al. (2012).

Comparing among pollution events in this study, the $E_{\text {abs }}$ $(781 \mathrm{~nm})$ values for the long-range-transported continental outflow (13 and 14 May) were larger (>1.3) than those for the air masses likely affected by emissions from the main island of Japan (6 and 10 May), as listed in Table 2. These results are consistent with the results of the SP2 and TEM analyses. Greater count fractions of thickly coated BC were observed in the SP2 measurements (Fig. 6), and a greater number fraction of coated soot particles (Table 3 ) and lower volume fraction of soot in smaller particles $(<0.6 \mu \mathrm{m})(\mathrm{Ta}-$ ble 4) were observed in samples $C$ and D compared to samples A and B. In addition, number fractions of coated soot particles were greater during the high- $E_{\text {abs }}$ events (samples $\mathrm{C}$ and D) compared to samples A and B (Table 5). The greater circularity of the soot-containing particles in samples $\mathrm{C}$ and D (Table 4, Fig. 10c) may also contribute to the greater $E_{\mathrm{abs}}$ values, as discussed by Adachi et al. (2010). Although most soot-containing particles in all samples in this study were internally mixed with sulfate and organics, the number fraction of thickly coated soot was higher in more aged air masses from China. Our results indicate that, according to the transport pathway and aging levels of the air mass, the magnitude of the lensing effect could change with changes in the mixing states and morphology of soot-containing particles.

\section{Summary and conclusions}

To elucidate the lensing effect of aged BC particles and their relation with the mixing state and morphology of individual particles, in situ measurements of the optical and chemical properties and size distributions of aerosols and the mixing state of $\mathrm{rBC}$, as well as sampling for TEM analysis, were conducted at an Asian outflow site in Noto Peninsula, Japan, in spring 2013.

The enhancement factor, $E_{\mathrm{abs}}(\lambda)$, at 405,532 , and $781 \mathrm{~nm}$ was determined by comparing the light absorption of aerosol particles with and without passing through a TD maintained at 300 or $400^{\circ} \mathrm{C}$. The $E_{\text {abs }}$ values tended to be lower at shorter wavelengths. In samples exhibiting a relatively small enhancement of light absorption at $405 \mathrm{~nm}$ after passage of the particles through the TD (samples A and B), spherical, 
carbon-rich particles were found, implying that the brownish materials may be formed during the heating processes.

The $E_{\text {abs }}(781 \mathrm{~nm})$ values estimated using the data at the TD temperature of $300^{\circ} \mathrm{C}$, which was assumed to represent the magnitude of the lensing effect, were 1.22 on average. Large $E_{\text {abs }}(781 \mathrm{~nm})$ values (> 1.3) were observed on 13-14 May when the air mass was transported over 2-3 days from urban areas in China. In the samples collected on 13-14 May (samples $\mathrm{C}$ and D), most soot-containing particles were internally mixed with a large amount of coating materials involving sulfate. Results of SP2 measurement and TEM analyses indicated that the number proportion of thickly coated soot particles tended to be greater in these air masses. In addition, most soot-containing particles in samples $\mathrm{C}$ and $\mathrm{D}$ were close to a spherical shape, whereas larger number fractions of soot-containing particles were mixed with clusters of sulfatecontaining spherules in samples $\mathrm{A}$ and $\mathrm{B}$. These results suggest that the mixing state and morphological features of sootcontaining particles would be factors controlling the lensing effect of BC in this study. The relation between the magnitude of the lensing effect and the mixing state and morphology of individual soot-containing particles for well-aged air masses will be useful to evaluate the direct radiative forcing of aerosols, particularly in leeward areas of large emission sources of BC.

\section{The Supplement related to this article is available online at doi:10.5194/acp-16-2525-2016-supplement.}

Acknowledgements. We express our gratitude to M. Sawano, S. Kagami (Kanazawa Univ.), and T. Yamasaki (Nagoya Univ.) for assisting our research. We gratefully acknowledge the NOAA Air Resources Laboratory (ARL) for providing the HYSPLIT transport model (http://www.arl.noaa.gov/ready.html). This work was performed with the support of the Grant-in-Aid for Scientific Research (KAKENHI 25701001 and 25740013) and Green Network of Excellence- Environmental Information (GRENE-ei) program from the Ministry of Education, Culture, Sports, Science and Technology (MEXT), the Global Environment Research Fund (2-1403) of the Ministry of the Environment, Japan, Toyoaki Scholarship Foundation, and the joint research program of the Solar-Terrestrial Environment Laboratory, Nagoya University.

Edited by: A. Petzold

\section{References}

Adachi, K. and Buseck, P. R.: Internally mixed soot, sulfates, and organic matter in aerosol particles from Mexico City, Atmos. Chem. Phys., 8, 6469-6481, doi:10.5194/acp-8-6469-2008, 2008.

Adachi, K. and Buseck, P. R.: Atmospheric tar balls from biomass burning in Mexico, J. Geophys. Res.-Atmos., 116, D05204, doi:10.1029/2010JD015102, 2011.

Adachi, K. and Buseck, P. R.: Changes of ns-soot mixing states and shapes in an urban area during CalNex, J. Geophys. Res.-Atmos., 118, 3723-3730, doi:10.1002/jgrd.50321, 2013.

Adachi, K., Chung, S. H., and Buseck, P. R.: Shapes of soot aerosol particles and implications for their effects on climate, J. Geophys Res., 115, D15206, doi:10.1029/2009JD012868, 2010.

Adachi, K., Zaizen, Y., Kajino, M., and Igarashi, Y.: Mixing state of regionally transported soot particles and the coating effect on their size and shape at a mountain site in Japan, J. Geophys. Res.Atmos., 119, 5386-5396, doi:10.1002/2013JD020880, 2014.

Alexander, D. T. L., Crozier, P. A., and Anderson, J. R.: Brown carbon spheres in East Asian outflow and their optical properties, Science, 321, 833-836, doi:10.1126/science.1155296, 2008.

Andreae, M. O. and Gelencsér, A.: Black carbon or brown carbon? The nature of light-absorbing carbonaceous aerosols, Atmos. Chem. Phys., 6, 3131-3148, doi:10.5194/acp-6-3131-2006, 2006.

Bond, T. C. and Bergstrom, R. W.: Light absorption by carbonaceous particles: An investigative review, Aerosol Sci. Tech., 40, 27-67, doi:10.1080/02786820500421521, 2006.

Bond, T. C., Streets, D. G., Yarber, K. F., Nelson, S. M., Woo, J.-H., and Klimont, Z.: A technology-based global inventory of black and organic carbon emissions from combustion, J. Geophys. Res., 109, D14203, doi:10.1029/2003JD003697, 2004.

Bond, T. C., Habib, G., and Bergstrom, R. W.: Limitations in the enhancement of visible light absorption due to mixing state, J. Geophys. Res., 111, D20211, doi:10.1029/2006JD007315, 2006.

Bond, T. C., Doherty, S. J., Fahey, D. W., Forster, P. M., Berntsen, T., DeAngelo, B. J., Flanner, M. G., Ghan, S., Kärcher, B., Koch, D. Kinne, S., Kondo, Y., Quinn, P. K., Sarofim, M. C., Schultz, M. G., Schulz, M., Venkataraman, C., Zhang, H., Zhang, S., Bellouin, N., Guttikunda, S. K., Hopke, P. K., Jacobson, M. Z., Kaiser, J. W., Klimont, Z., Lohmann, U., Schwarz, J. P., Shindell, D., Storelvmo, T., Warren, S. G., and Zender, C. S.: Bounding the role of black carbon in the climate system: A scientific assessment, J. Geophys. Res.-Atmos., 118, 5380-5552, doi:10.1002/jgrd.50171, 2013.

Cappa, C. D., Onasch, T. B., Massoli, P., Worsnop, D. R., Bates, T. S., Cross, E. S., Davidovits, P., Hakala, J., Hayden, K. L., Jobson, B. T., Kolesar, K. R., Lack, D. A., Lerner, B. M., Li, S. M., Mellon, D., Nuaaman, I., Olfert, J. S., Petaja, T., Quinn, P. K., Song, C., Subramanian, R., Williams, E. J., and Zaveri, R. A.: Radiative absorption enhancements due to the mixing state of atmospheric black carbon, Science, 337, 1078-1081, doi:10.1126/science.1223447, 2012.

Chan, T. W., Brook, J. R., Smallwood, G. J., and Lu, G.: Time-resolved measurements of black carbon light absorption enhancement in urban and near-urban locations of southern Ontario, Canada, Atmos. Chem. Phys., 11, 10407-10432, doi:10.5194/acp-11-10407-2011, 2011. 
Draxler, R. R. and Rolph, G. D., 2003. HYSPLIT (HYbrid SingleParticle Lagrangian Integrated Trajectory) Model access via NOAA ARL READY Website, available at: http://www.arl.noaa. gov/ready/hysplit4.htm (last access: 3 October 2013), NOAA Air Resources Laboratory, Silver Spring, MD.

Fuchs, N. A.: The coagulation of aerosols, in The mechanics of aerosols, Dover Publications, Inc., New York, 288-322, 1964.

Gao, R. S., Schwarz, J. P., Kelly, K. K., Fahey, D. W., Watts, L. A., Thompson, T. L., Spackman, J. R., Slowik, J. G., Cross, E. S., Han, J. H., Davidovits, P., Onasch, T. B., and Worsnop, D. R.: A novel method for estimating lightscattering properties of soot aerosols using a modified singleparticle soot photometer, Aerosol Sci. Tech., 41, 125-135, doi:10.1080/02786820601118398, 2007.

Gao, J., Wang, T., Zhou, X., Wu, W., and Wang, W.:Measurement of aerosol number size distributions in the Yangtze River delta in China: Formation and growth of particles under polluted conditions, Atmos. Environ., 43, 829-836, doi:10.1016/j.atmosenv.2008.10.046, 2009.

Guo, X., Nakayama a, T., Yamada, H., Inomata, S., Tonokura, K., and Matsumi, Y.: Measurement of the light absorbing properties of diesel exhaust particles using a three-wavelength photoacoustic spectrometer, Atmos. Environ., 94, 428-437, doi:10.1016/j.atmosenv.2014.05.042, 2014.

Hasegawa, S. and Ohta, S.: Some measurements of the mixing state of soot-containing particle at urban and non-urban sites, Atmos. Environ., 36, 3899-3908, doi:10.1016/S1352-2310(02)00343-6, 2002.

Healy, R. M., Wang, J. M., Jeong, C.-H., Lee, A. K. Y., Willis, M. D., Jaroudi, E., Zimmerman, N., Hilker, N., Murphy, M., Eckhardt, S., Stohl, A., Abbatt, J. P. D., Wenger, J. C., and Evans, G. J., Light-absorbing properties of ambient black carbon and brown carbon from fossil fuel and biomass burning sources, J. Geophys. Res.-Atmos., 120, 6619-6633, doi:10.1002/2015JD023382, 2015.

Husar, R. B. and Whitby, K. T.: Growth Mechanisms and size spectra of photochemical aerosols, Environ. Sci. Technol., 7, 241247, doi:10.1021/es60075a003, 1973.

Intergovernmental Panel on Climate Change (IPCC), Climate Change 2013: The Physical Science Basis, Cambridge Univ. Press, Cambridge, UK, 2013.

Iseki, S., Sadanaga, Y., Matsuki, A., Iwasaka, Y., Sato, K., Takenaka, N., and Bandow H.: Analyses of the concentration variations of ozone and carbon monoxide at Suzu, the Noto Peninsula, J. Jpn. Soc. Atmos. Environ., 45, 256-263, doi:10.11298/taiki.45.256, 2010 (in Japanese).

Ishiyama, A., Takaji, R., Sadanaga, Y., Matsuki, A., Sato, K., Osada, K., and Bandow, H.: Seasonal variations of peroxyacyl nitrates and alkyl nitrates concentrations at Suzu, the Noto Peninsula, J. Jpn. Soc. Atmos. Environ., 50, 16-26, 2015 (in Japanese).

Johnson, K. S., Zuberi, B., Molina, L. T., Molina, M. J., Iedema, M. J., Cowin, J. P., Gaspar, D. J., Wang, C., and Laskin, A.: Processing of soot in an urban environment: case study from the Mexico City Metropolitan Area, Atmos. Chem. Phys., 5, 3033-3043, doi:10.5194/acp-5-3033-2005, 2005.

Knox, A., Evans, G. J., Brook, J. R., Yao, X., Jeong, C.-H., Godri, K. J., Sabaliauskas, K., and Slowik, J. G.: Mass absorption cross-section of ambient black carbon aerosol in re- lation to chemical age, Aerosol Sci. Technol., 43, 522-532, doi:10.1080/02786820902777207, 2009.

Kurokawa, J., Ohara, T., Morikawa, T., Hanayama, S., JanssensMaenhout, G., Fukui, T., Kawashima, K., and Akimoto, H.: Emissions of air pollutants and greenhouse gases over Asian regions during 2000-2008: Regional Emission inventory in ASia (REAS) version 2, Atmos. Chem. Phys., 13, 11019-11058, doi:10.5194/acp-13-11019-2013, 2013.

Lack, D. A. and Cappa, C. D.: Impact of brown and clear carbon on light absorption enhancement, single scatter albedo and absorption wavelength dependence of black carbon, Atmos. Chem Phys., 10, 4207-4220, doi:10.5194/acp-10-4207-2010, 2010.

Lack, D. A., Langridge, J. M., Bahreini, R., Cappa, C. D., Middlebrook, A. M., and Schwarz, J. P.: Brown carbon and internal mixing in biomass burning particles, P. Natl. Acad. Sci. USA, 109, 14802-14807, doi:10.1073/pnas.1206575109, 2012.

Li, J., Pósfai, M., Hobbs, P. V., and Buseck, P. R.: Individual aerosol particles from biomass burning in southern Africa: 2, Compositions and aging of inorganic particles, J. Geophys. Res., 108, 8484, doi:10.1029/2002JD002310, 2003.

Li, W. J., Shao, L. Y., and Buseck, P. R.: Haze types in Beijing and the influence of agricultural biomass burning, Atmos. Chem Phys., 10, 8119-8130, doi:10.5194/acp-10-8119-2010, 2010.

Li, W., Wand, T., Zhou, S., Lee, S. C., Huang, Y., Gao, Y., and Wang, W.: Microscopic observation of metal-containing particles from Chinese continental outflow observed from a Non-Industrial Site, Environ. Sci. Technol., 4, 9124-9131, doi:10.1021/es400109q, 2013.

Liu, S. Aiken, A. C., Gorkowski, K., Dubey, M. K., Cappa, C. D., Williams, L. R., Herndon, S. C., Massoli, P., Fortner, E. C., Chhabra, P. S., Brooks, W. A., Onasch, T. B., Jayne, J. T., Worsnop, D. R., China, S., Sharma, N., Mazzoleni, C., Xu, L., Ng, N. L., Liu, D., Allan, J. D., Lee, J. D., Fleming, Z. L., Mohr, C., Zotter, P., Szidat, S., and Prévôt, A. S. H., Enhanced light absorption by mixed source black and brown carbon particles in UK winter, Nature Comm., 6, 8435, doi:10.1038/ncomms9435, 2015.

Ma, X., Yu, F., and Luo, G.: Aerosol direct radiative forcing based on GEOS-Chem-APM and uncertainties, Atmos. Chem. Phys., 12, 5563-5581, doi:10.5194/acp-12-5563-2012, 2012.

Ma, X., Yu, F., and Luo, G.: Aerosol direct radiative forcing based on GEOS-Chem-APM and uncertainties, Atmos. Chem. Phys., 12, 5563-5581, doi:10.5194/acp-12-5563-2012, 2012.

Maki, T., Susuki, S., Kobayashi, F., Kakikawa, M., Tobo, Y., Yamada, M., Higashi, T., Matsuki, A., Hong, C., Hasegawa, H., and Iwasaka, Y.: Phylogenetic analysis of atmospheric halotolerant bacterial communities at high altitude in an Asian dust (KOSA) arrival region, Suzu City, Sci. Total Environ., 408, 4556-4562, doi:10.1016/j.scitotenv.2010.04.002, 2010.

Mamane, Y. and Gottlieb, J.: The study of heterogeneous reactions of carbonaceous particles with sulfur and nitrogen oxides using single particles. J. Aerosol. Sci. 20, 575-584, doi:10.1016/00218502(89)90104-3, 1989.

Meng, Z. and Seinfeld, J. H.: On the source of submicrometer droplet mode of urban and regional aerosols, Aerosol Sci. Tech., 20, 253-265, 1994.

Moosmüller, H., Chakrabarty, R. K., and Arnott, W. P.: Aerosol light absorption and itsmeasurement: A review, J. Quant. Spectrosc. 
Radiat. Transfer, 110, 844-878, doi:10.1016/j.jqsrt.2009.02.035, 2009.

Moteki, N. and Kondo, Y.: Effects of Mixing State on Black Carbon Measurements by Laser-Induced Incandescence, Aerosol Sci. Tech., 41, 398-417, doi:10.1080/02786820701199728, 2007.

Murr, L. E. and Soto, K. F.: A TEM study of soot, carbon nanotubes, and related fullerene nanopholyhedra in common fuel-gas combustion sources, Mater. Charact., 55, 50-65, 2005.

Nakayama, T., Sato, K., Matsumi, Y., Imamura, T., Yamazaki, A., and Uchiyama, A.: Wavelength and $\mathrm{NO}_{x}$ dependent complex refractive index of SOAs generated from the photooxidation of toluene, Atmos. Chem. Phys., 13, 531-545, doi:10.5194/acp-13531-2013, 2013.

Nakayama, T., Ikeda, Y., Sawada, Y., Setoguchi, Y., Ogawa, S., Kawana, K., Mochida, M., Ikemori, F., Matsumoto, K., and Matsumi, Y.: Properties of light-absorbing aerosols in the Nagoya urban area, Japan, in August 2011 and January 2012: Contributions of brown carbon and lensing effect, J. Geophys. Res.-Atmos., 119, 12721-12739, doi:10.1002/2014JD021744, 2014.

Nakayama, T., Suzuki, H., Kagaminani, S., Ikeda, Y., Uchiyama, A., and Matsumi, Y.: Characterization of a three wavelength photoacoustic soot spectrometer (PASS-3) and a photoacoustic extinctiometer (PAX), J. Metorol. Soc. Jpn., 93, 285-308, doi:10.2151/jmsj.2015-016, 2015.

Ng, N. L., Herndon, S. C., Trimborn, A., Canagaratna, M. R., Croteau, P. L., Onasch, T. B., Sueper, D., Worsnop, D. R., Zhang, Q., Sun, Y. L., and Jayne, J. T.: An Aerosol Chemical Speciation Monitor (ACSM) for Routine Monitoring of the Composition and Mass Concentrations of Ambient Aerosol, Aerosol Sci. Tech., 45, 780-794, doi:10.1080/02786826.2011.560211, 2011.

Okada, K.: Nature of individual hygroscopic particles in the urban atmosphere, J. Meteor. Soc. Japan, 61, 727-735, 1983.

Ohara, T., Akimoto, H., Kurokawa, J., Horii, N., Yamaji, K., Yan, $\mathrm{X}$., and Hayasaka, T.: An Asian emission inventory of anthropogenic emission sources for the period 1980-2020, Atmos. Chem. Phys., 7, 4419-4444, doi:10.5194/acp-7-4419-2007, 2007.

Pósfai, M., Anderson, J. R., and Buseck, P. R.: Soot and sulfate aerosol particles in the remote marine troposphere, J. Geophys. Res., 104, 685-693, doi:10.1029/1999JD900208, 1999.

Pósfai, M., Simonics, R., Li, J., Hobbs, P. V., and Buseck, P. R..: Individual aerosol particles from biomass burning in southern Africa: 1. Compositions and size distributions of carbonaceous particles, J. Geophys. Res., 108, 8483, doi:10.1029/2002JD002291, 2003.

Pósfai, M., Gelencser, A., Simonics, R., Arato, K., Li, J., Hobbs, P. V., and Buseck, P. R.: Atmospheric tar balls: Particles from biomass and biofuel burning, J. Geophys. Res., 109, D06213, doi:10.1029/2003JD004169, 2004.

Ramanathan, V. and Carmichael, G.: Global and regional climate changes due to black carbon, Nature Geosci., 1, 221-227, doi:10.1038/ngeo156, 2008.

Rolph, G. D.: Real-time environment applications and display system (READY), NOAA Air Resour. Lab., Silver Spring, Md., available at: http://www.arl.noaa.gov/ready/hysplit4.html (last access: 3 October 2013), 2003.

Sadanaga, Y., Yuba, A., Kawakami, J., Takenaka, N., Yamamoto, M., and Bandow, H.: A gaseous nitric acid analyzer for the remote atmosphere based on the scrubber difference/NO- ozone chemiluminescence method, Anal. Sci., 24, 967-971, doi:10.2116/analsci.24.967, 2008.

Sadanaga, Y., Fukumori, Y., Kobashi, T., Nagata, M., Takenaka, N., and Bandow, H.: Development of a selective lightemitting diode photolytic $\mathrm{NO}_{2}$ converter for continuously measuring $\mathrm{NO}_{2}$ in the atmosphere, Anal. Chem., 82, 9234-9239, doi:10.1021/ac101703z, 2010.

Shi, Z., Zhang, D., Ji, H., Hasegawa, S., and Hayashi, M.: Modification of soot by volatile species in an urban atmosphere, Sci. Total Environ., 389, 195-201, doi:10.1016/j.scitotenv.2007.08.016, 2008.

Streets, D. G., Bond, T. C., Carmichael, G. R., Fernandes, S. D., Fu, Q., He, D., Klimont, Z., Nelson, S. M., Tsai, N. Y., Wang, M. Q., Woo, J.-H., and Yarber, K. F.: An inventory of gaseous and primary aerosol emissions in Asia in 2000, J. Geophys. Res., 108, 8809, doi:10.1029/2002JD003093, 2003.

Takami, A., Miyoshi, T., Shimono, A., and Hatakeyama, S. : Chemical composition of fine aerosol measured by AMS at Fukue Island, Japan during APEX period, Atmos. Environ., 39, 49134924, doi:10.1016/j.atmosenv.2005.04.038, 2005.

Takami, A., Miyoshi, T., Shimono, A., Kaneyasu, N., Kato, S., Kajii, Y., and Hatakeyama, S.: Transport of anthropogenic aerosols from Asia and subsequent chemical transformation, J. Geophys. Res., 112, D22S31, doi:10.1029/2006JD008120, 2007.

Ueda, S., Osada, K., and Takami, A.: Morphological features of soot-containing particles internally mixed with watersoluble materials in continental outflow observed at Cape Hedo, Okinawa, Japan, J. Geophys. Res., 116, D17207, doi:10.1029/2010JD015565, 2011.

Ueda, S., Hirose, Y., Miura, K., and Okochi, H.: Individual aerosol particles in and below clouds along a Mt. Fuji slope: Modification of sea-salt-containing particles by in-cloud processing, Atmos. Res., 137, 216-227, D17207, doi:10.1016/j.atmosres.2010.10.021, 2014.

Vester, B. P., Ebert, M., Barnert, E. B., Schneider, J., Kandler, K., Schütz, L., and Weinbruch, S.: Composition and mixing state of the urban background aerosol in the RheinMain area (Germany), Atmos. Environ., 41, 6102-6115, doi:10.1016/j.atmosenv.2007.04.021, 2007.

Weingartner, E., Burtscher, H., and Baltensperger, U.: Hygroscopic properties of carbon and diesel soot particles, Atmos. Environ., 31, 2311-2327, doi:10.1016/S1352-2310(97)00023-X, 1997.

Yang, H. and Yu, Z.: Uncertainties in charring correction in the analysis of elemental and organic carbon in atmospheric particles by thermal/optical methods, Environ. Sci. Technol., 36, 5199-5204, doi:10.1021/es025672z, 2002.

Yu, J. Z., Xu, J., and Yang, H.: Charring characteristics of atmospheric organic particulate matter in Thermal Analysis, Environ Sci. Technol., 36, 754-761, doi:10.1021/es015540q, 2002.

Yuba, A., Sadanaga, Y., Takami, A., Hatakeyama, S., Takenaka, N., and Bandow, H.: Measurement system for particulate nitrate based on the scrubber difference $\mathrm{NO}_{3} \mathrm{O}_{3}$ chemiluminescence method in remote areas, Anal. Chem., 82, 8916-8921, doi:10.1021/ac101704w, 2010.

Yuba, A., Sadanaga, Y., Takami, A., Hatakeyama, S., Takenaka, N., Yoshihiko, M., Ohara, T., Yonemura, S., Kato, S., Kajii, Y., and Bandow, H.: Concentration variations of total reactive nitrogen and total nitrate during transport to Fukue Island and to Cape 
Hedo, Japan in the marine boundary layer, Atmos. Environ., 97, 471-478, doi:10.1016/j.atmosenv.2014.04.010, 2014.
Zuberi, B., Johnson, K. S., Aleks, G. K., Molina, L. T., and Molina, M. J.: Hydrophilic properties of aged soot, Geophys. Res. Lett., 32, L01807, doi:10.1029/2004GL021496, 2005. 